TE WHARE WĀNANGA O TE ŪPOKO O TE IKA A MĀUI

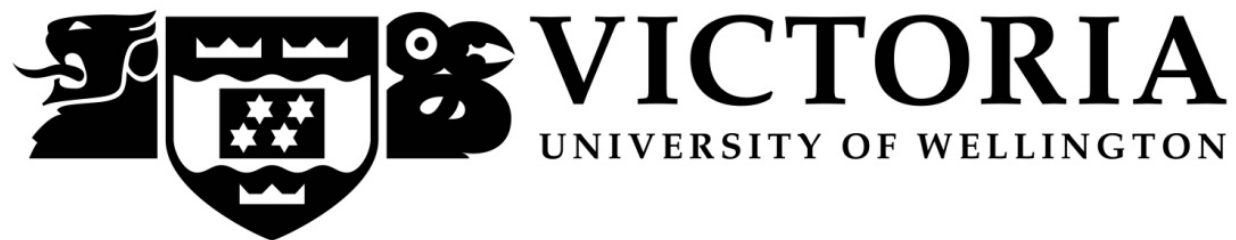

\title{
Who's contributing? Do personality traits influence the level and type of participation in online community?
}

MMIM592

by

Sarah Morse

300137056

Supervisor: Professor Rowena Cullen

Submitted to the School of Information Management,

Victoria University of Wellington

in partial fulfilment of the requirements for the degree of

Master of Information Management

Friday 23rd October 2009 


\section{TABLE OF CONTENTS}

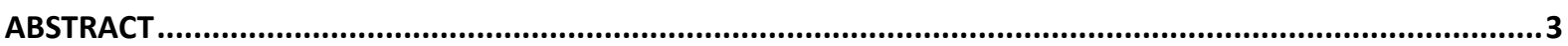

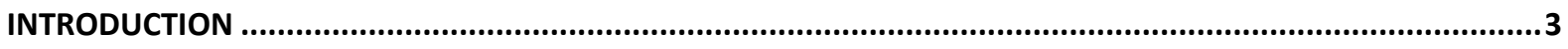

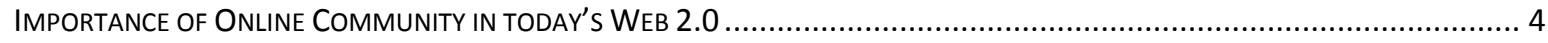

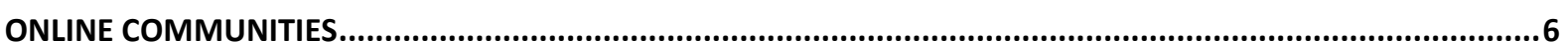

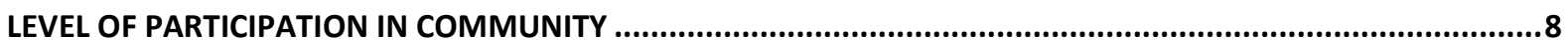

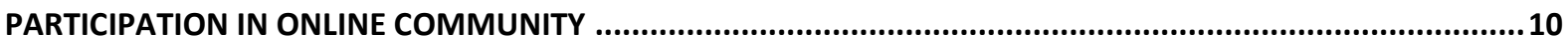

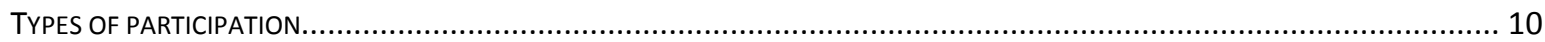

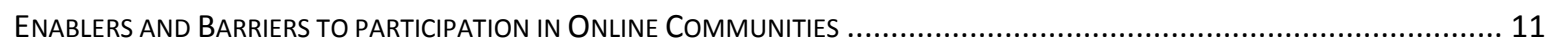

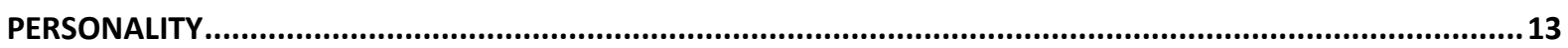

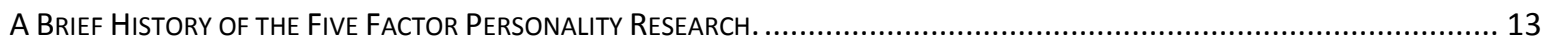

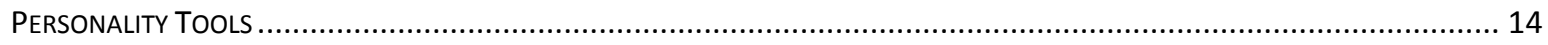

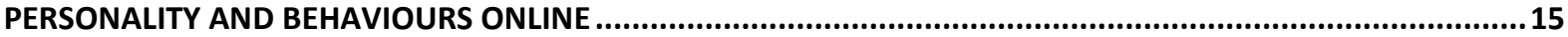

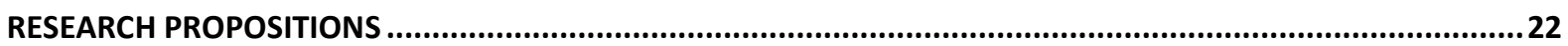

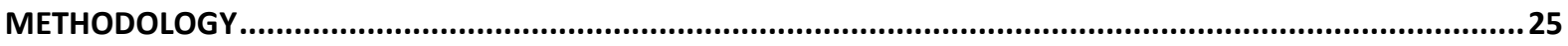

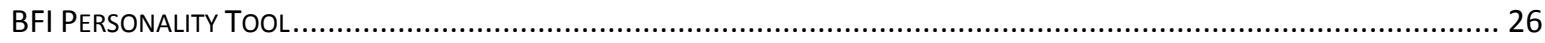

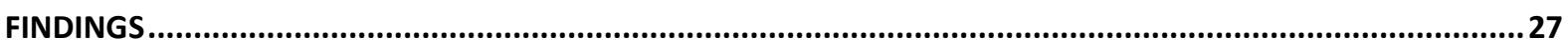

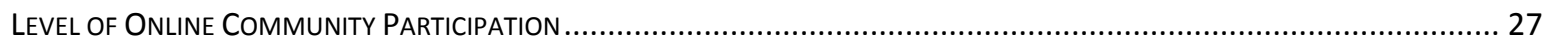

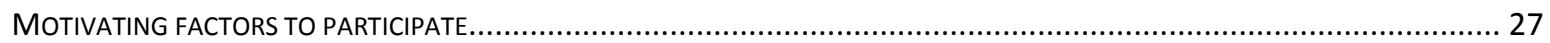

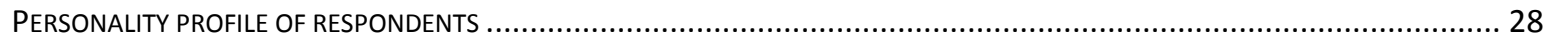

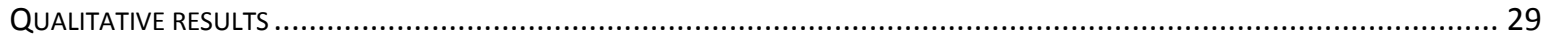

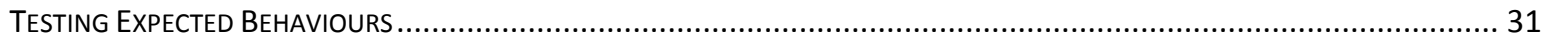

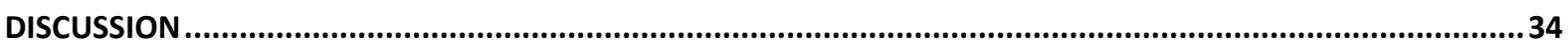

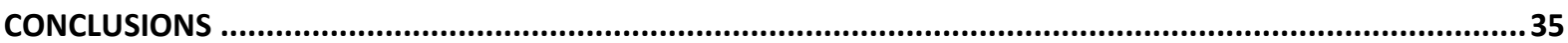

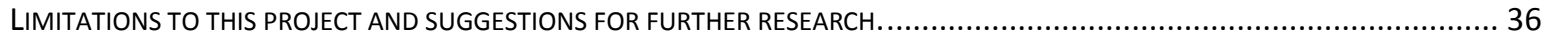

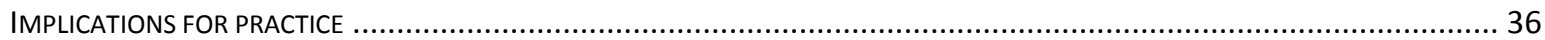

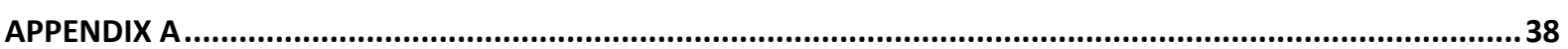

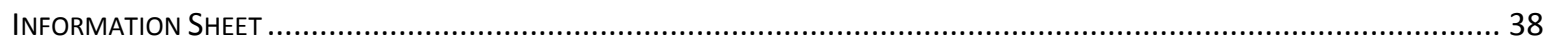

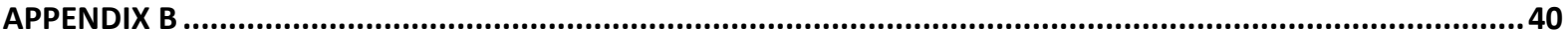

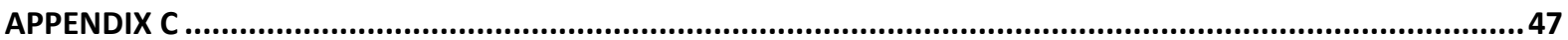

BREAKDOWN OF PARTICIPATION MOTIVATORS SPLIT ACROSS THE GENDERS. .......................................................... 47

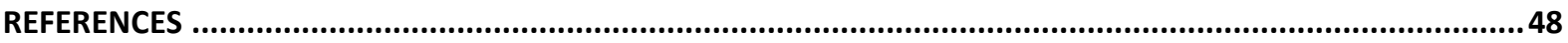




\section{ABSTRACT}

Purpose: The purpose of this research paper is to find out if personality traits have any influence on the level and type of participation in online communities.

Aim: The aim of this paper is to find out if the small number of active participants in online communities are dominated by a particular personality trait, and if personality traits influence how much and what type of participation an individual undertakes in online communities.

Method: An online survey was used to gather both participation types and levels and to measure personality, using the Big Five Inventory, 44 item tool.

Findings: Personality does have an influence on what type of participation individuals undertake in online communities. Individuals displaying high in extraversion traits are less likely to be active in online communities but when they do they identify with a sense of friendship. Individuals displaying high in neurotic traits are less likely to be active in online communities but when they do they are motivated by a sense of belonging. Individuals high in conscientiousness traits are more likely to be motivated to participate by sharing useful information. Individuals high in a combination of conscientiousness and agreeable traits were motivated to participate to share useful information. There was no evidence to suggest that those that do participate are dominated by a particular personality type. What was evident was that individuals high in certain personality traits are less likely to participate in certain content activity. This means that communities that engage in specific content type or activity may be skewed to particular personality types. More in-depth research would be required on one type of community in order to investigate this further.

\section{INTRODUCTION}

Do personality traits influence the level and type of participation in online communities? 
Online communities are becoming increasingly prevalent with the growing popularity of Web 2.0 sites. Web 2.0 is a broad definition term to describe new generation web sites and services that encompass interactive information sharing, interoperability, user-centered design and collaboration on the internet (Sharma, 2008). Online Communities are part of Web 2.0, as they support information sharing, and collaborative content generation amongst its users.

There is, however, a participation inequality in the user generated content within online communities. It is estimated that only $1 \%$ of a community's audience will be active contributors of content (Neilson, 2006). Research has indicated a number of enablers and barriers to participation in online communities. Personality has been shown to be an indicator of various types of online behaviour many of these behaviours could indicate level and type of participation within communities. Personality traits could therefore influence the type and level of participation within online community. There has been no published research to date into whether personality influences participation in online communities. The purpose of this research paper is to seek the answers to the following questions. Do personality traits influence how an individual participates in online community? Are certain personality traits indicative of particular behaviours within online community? If personality does influence how individuals behave online, are the relatively small number of individuals who are participating dominated by a particular personality trait?

\section{IMPORTANCE OF ONLINE COMMUNITY IN TODAY'S WEB 2.0}

McKinsey Quarterly surveyed companies over a period of two years on Web 2.0 adoption. They define participative technologies as the cornerstone of Web 2.0:

"Web 2.0 technologies are interactive and require users to generate new information and content or to edit the work of the other participants." (Chui, Miller, and Roberts, 2009) According to Neilson/NetRatings (2006), user-generated content sites drove over half of the top 10 fastest growing websites in the US in 2006.

Web 2.0 and user-generated content is becoming an important tool for online marketers, entrepreneurs and academics alike (Chui et.al. 2009). If we are able to understand more about how and why people participate and contribute to content in an online community, then we can begin to understand the nature of it. 
Web 2.0 encompasses a range of technologies, defined by McKinsey (2009) as, blogs, wikis, podcasts, information tagging, prediction markets and social networks, most of which can also be defined as online community user generated content. For example this would include; Wikipedia, review sections of sites such as Amazon, Internet Movie Database (IMDB) etc, Message boards, customer review sites, and blogs that maintain dialogue between the creator and commenter.

As the increasing popularity of online communities grows, interest from practioners, consultants and researchers has also grown. Deloitte (2008) published a survey on the enterprise value of online communities. They state that "communities can assist organizations in 'transformative' ways - by tapping into new talent, helping to design products and services, providing customer support and building the brand within the community" (Deloitte, 2008). Forester (2008) supports this view noting that online communities can help companies build high levels of consumer loyalty, by reinforcing the brand and creating product evangelists. If this consultant practitioner research of Forrester, McKinsey Quarterly and Deloittes are to be believed then online community is the transformational way forward in communicating with customers.

Within e-government, public agencies are being encouraged to use communities and social software to provide a platform for citizen engagement in government process. (State Services Commission, 2007).

Two examples in New Zealand to date are:

Police Act 2008 Wiki: which enabled citizen engagement and consultation into the wording of the Police Act. (NZ Police, 2007)

The Bio Ethics Council produced a report "Who gets born?" (Bioethics Council of New Zealand, 2009) on pre birth testing, which was produced from a consultative exercise of deliberative public dialogue, that was partly conducted within online discussion forums. The outcomes of these two projects have been heralded as pioneers in utilizing online community and Web 2.0 to obtain citizen engagement within government process. (BBC, 2007)

E-government initiatives are also encouraging citizen involvement in online spaces. (State Services Commission, 2007), this is partly why some consultants in the industry (McKinsey, Deloittes) see online communities as having transformational potential for communicating between and within groups. 
Outside demographic information, there is very little research about who is contributing online giving rise to the questions:

- What if there is a'type' of person who participates in an online community?

- What would this mean to companies and governments who presume a 'representative' sample of their customers/citizens.

- How can understanding what type of person and why and how they participate in online community influence how future online community sites are built and managed?

\section{Online Communities}

A community can be defined as "groups of people who share common interest, beliefs and values and who interact in some mediated way." (Bruce \& Yearley. 2006) Membership of a community is termed as a 'voluntary association', meaning that for individuals to be a part of a community there needs to be an active membership. Ethnic groups or fans of a performer would not be considered a 'community' under this definition.

Online community can be defined along similar lines, with the added element of being mediated through an electronic/computer generated/internet or intranet based online environment.

Preece (2000) provides a holistic definition of online communities in her book "Online Communities". She details her definition across four high level dimensions of people, shared purpose, policies and computer systems.

"People, who interact socially as they strive to satisfy their own needs or perform special roles, such as leading or moderating.

A shared purpose, such as an interest need, information exchange, or service that provides a reason for the community.

Policies, in the form of tacit assumptions, rituals, protocols, rules and laws that guide people's interactions.

Computer systems, to support and mediate social interaction and facilitate a sense of togetherness."

(Preece, 2000. Pg10.) 
Other definitions discuss the core criteria as groups of people who share common interest communicating together, where the interaction is at least partly supported by technology. (Porter, 2004; Riddings \& Gefen, 2004)

Jones (1997) makes the important point that there is a sociological phenomenon required to determine the difference between individuals connecting using computer mediated communication $(\mathrm{CMC})$ and those that use $\mathrm{CMC}$ to enable an online community. This sociological aspect to $\mathrm{CMC}$ is defined as sense of community which is also identified by Blanchard and Markus, (2002) and McMillan and Chavis (1986)

This important distinction between Virtual Community and Virtual Settlement as explained by Blanchard and Markus, (2002) Jones (1997) and McMillan and Chavis (1986) is that the participants identified a "Sense of Community". In other words, for a virtual settlement to be considered a virtual community there is a requirement for a connection, or affective bonds between the members of the community, for them to become a virtual community. Using this definition, social networking sites are not considered an online community due to the fact that the only shared interest relates to having a profile on the site. While affective bonds may exist between individual members, this represents a network structure, rather than a cohesive community, or 'sense of community' with a defined membership. There are however online communities that exist within the social networking sites, such as interest groups, fan groups etc. As membership of these sub groups is optional, presence alone within a social networking site will not be considered as participation in online community. The most succinct definition however, is the oldest in the very early years of the internet by Rheingold (1993) when he defined an online community as technology supported selforganizing, social collective, created and sustained through the communication efforts of voluntary participants who are socially and geographically dispersed. Which brings together many of same concepts identified above.

The literature reviewed on online community all identify an important social constructs to it, and that the technology and computer mediated communication are both important defining aspects.

For this reason, and for the purpose of this paper, Online Community will be defined as a dispersed group of people who interact online to share and exchange information, where the content is driven by the group. 


\section{LeVel of Participation in Community}

Research into participation in online community is preceded by research into participation in offline community, or community with a physical presence to the interaction, such as sports clubs, special interest groups and community groups.

Wandersman (1981) details a framework of participation in face to face community organizations describing different types of participant in communities within four levels of activity:

- Non participant

- A member who attends meetings, comments and votes

- A worker who joins committees and does work

- A leader who defines goals and chooses tasks

Bento \& Schuster (2005) discusses a framework within an online learning environment and provide a taxonomy of participation by students in online courses, which bears some similarity to the levels described by Wandersman (1981).

\begin{tabular}{|l|l|l|}
\hline Interpersonal & Quadrant III & Quadrant IV \\
HIGH & "Social Participants" & \\
\hline Interpersonal & Quadrant I & Quadrant II \\
Interaction - & "Missing in Action" & "Witness Learners" \\
LOW & & \\
\hline & Interaction with Content - LOW & Interaction with Content - HIGH \\
\hline
\end{tabular}

Figure1: Bento \& Schuster (2005) Taxonomy of Participation in Online Courses.

Blanchard and Markus (2002) identify two generic types of participation levels in online communities in their research on Windows Messenger Communities (MSN); as active and passive participants. Active participants are those that participate actively, by creating content, while passive participants lurk and read what the active participants have contributed. Comparing this view with that of Wandersman (1981) and Bento \& Schuster (2005) there is a pattern of comparing active and passive participation with high and low interaction in the community.

The three frameworks of participation clearly identify four levels in relation to online community activity. Matching Bento \& Schuster's 'quadrants' with Wandersman's four levels, there is a continuum of activity level. Combining this with a continuum of passive to 
active participation determined by Blanchard and Markus, the following can be described or identified:

\begin{tabular}{|l|l|l|}
\hline Wandersman & Bento \& Schuster & Blanchard \& Markus \\
\hline Non participant & Missing in Action & Passive \\
\hline Attendee & Witness Learner & \\
\hline Joiner - actively does work & Social Participants & \\
\hline Leader & Active Learners & Active \\
\hline
\end{tabular}

Table 1. Synthesis of Wandersman, Bento \& Schuster and Blanchard \& Marcus participation models.

Wandersman (1981) describes his framework as a continuum of activity from non and low activity through to active activity and decision making. Bento \& Schuster (2005) split their four quadrants into two main areas of high and low interpersonal interaction. They describe their quadrants III and IV as active participants, while quadrants I and II as low or passive activity. The main difference is the matchup between Wandersman's 'attendee' level and Bento \& Schuster's 'witness learner'. Wandersman's implies a level of activity, while Bento and Schuster's implies a more passive approach. However, taken within context of the participation each is referring to; Wandersman in relation to community organization and Bento \& Schuster in relation to participation in online learning courses, these separate activities dictate different definitions of participation. Both, however, are passive participants, but are only slightly more active than the non-participants or missing in action students. Interestingly, non-participants are still considered part of the community, suggesting that those who voluntarily join a community organization, and perhaps identify a 'sense of community', do not need to participate in order to be considered part of that community.

This has interesting implications for online communities as to whether lurkers or nonparticipants are considered to be part of the community. As implied above, it is their own 'sense of community' that defines if they feel they are part of the community. Within an online environment, merely surfing to a web and reading an IMDB review does not make them part of the community. However creating a user account, which is voluntary and purposeful association, could be considered part of the community regardless of the level of participation they do. However, some authors have included silent participants in their 
definitions of online communities; those who read content but do not actively contribute (Riddings \& Gefen, 2004). But as this study will focus on the personality traits that influence participation in online community, only active participants will be focused on. While it is expected that lurkers may be surveyed and important data gathered about them, the focus of the data will be to examine what influences types and levels of participation, rather than what influences non-participation.

\section{Participation in Online Community}

The issue of motivation to participate in online community has been identified as a major factor in the success of online communities (Preece, 2000). Neilsen (2006) highlights the inequalities of membership to contributions in online communities with his 90:9:1 rule. This rule states that $90 \%$ of visitors to a list or forum will be passive readers, or lurkers of information, $9 \%$ will occasionally participate, and $1 \%$ will actively participate and contribute most of the content.

Practioners and consultants alike encourage sites to build large community bases to ensure that the number of contributors to the community will remain significant. This can be referred to as The Long Tail; encouraging a large user/reader base is one of the strategies for gaining community participation (Anderson, 2008).

Using Wikipedia (the free encyclopedia that anyone can edit, Wikipedia; 2009) as an example, the participant numbers are more exaggerated than Neilsen suggests. On the 'about us' page they state that they have 648 million unique visitors a year, or unique individuals reading and reviewing content on the site. In reality they have 75,000 active contributors creating content, which equates to about $0.012 \%$ active participants to readers of the site (Wikipedia, 2009). Seventy-five thousand active contributors is still a large pool of individuals to ensure the content on the site is kept up to date and relevant. This is why Wikipedia is a good example of what is meant by the long tail in regard to online community participation. This is why finding out what motivates active participation on online communities is important.

\section{TYPES OF PARTICIPATION}

Once an individual is participating within an online community there are many types of involvement. Joyce and Kraut (2006) explored how different types of participation in an 
online community may influence continued involvement in the community. They coded over 2777 entries within various newsgroups and developed the following codes for entries:

- Questions - if the entry asked a question

- Answers - if the entry sought to answer a question

- Statements - if the entry stated a fact or opinion

- Positive - if the entry contained positive language

- Negative - if the entry contained negative language.

Overall they found that the only predictor of continued participation within the groups related to those individuals who posted questions, were more likely to have those questions answered, and were subsequently more likely to continue participating. Their research did not show any correlation that either positive or negative language had any influence. We can see how different types of participation can lead directly on to how much an individual may participate. It has been suggested in the personality literature that different personality types may prefer different types of participation (Hamburger \& Ben-Artzi, 2000; Balthazard, Potter \& Warren, 2002; Rouse \& Haas, 2003; Byron \& Bladridge, 2007; Devaraj et. al. 2008), but this will be discussed in full below. It is important to discuss the enablers and barriers to participation first.

\section{ENABLERS AND BARRIERS TO PARTICIPATION IN ONLINE COMMUNITIES}

With the increasing popularity and importance of online communities, there has been a considerable amount of research into what the barriers and enablers are to encouraging participation in online communities. Beenen, Ling, Wang, Chang, and Frankowski, (2004) used a social psychology theory that, individuals who believed, or were led to believe their contributions were unique or for the betterment of the community, would contribute more. The practitioner literature of Preece (2000) and Neilson (2000) focuses on usability aspects of online community structure and technology aspects. Reward, for either quality of content or incentive to contribute has also been proven to affect an individual's contribution rate (Neilson, 2000; Hall \& Graham, 2004). Style and type of content, and the responses this content receives, has also been proved to be a motivating factor to participation which has been shown in a number of studies (Riddings \& Gefen, 2004; Joyce \& Kraut, 2006; Jones et. al. 2004). Barriers to participation have been identified broadly as; volume of information within the community (Jones \& Ravid, 2004); the usability aspects of the interface (Preece, 
2000); and how the user generated content is mediated and responded to (Sohn \& Leckenby, 2007).

Enablers and barriers to participation can be broadly divided into two main categories; human or technology. Human factors relate to the person, who is making, or not making, the contribution. Technology factors relate to how the online community is set up or designed. The following is a table summarising the reviewed literature on enablers and barriers for participation in online community:

\begin{tabular}{|c|c|c|c|}
\hline & Enablers & Barriers & Factor \\
\hline 1 & $\begin{array}{l}\text { Simplicity of information and responses } \\
\text { (Jones \& Ravid, 2004) }\end{array}$ & $\begin{array}{l}\text { Information Overload } \\
\text { within } \\
\text { community/group } \\
\text { (Jones \& Ravid, 2004) }\end{array}$ & $\begin{array}{l}\text { Technology/ } \\
\text { Human }\end{array}$ \\
\hline 2 & $\begin{array}{l}\text { Friendship within community members } \\
\text { (Riddings \& Gefen, 2004) }\end{array}$ & & Human \\
\hline 3 & $\begin{array}{l}\text { Sense of belonging } \\
\text { (Riddings \& Gefen, 2004) }\end{array}$ & & Human \\
\hline 4 & $\begin{array}{l}\text { Reassurance of unique contribution } \\
\text { (Beenen et. al. 2004) } \\
\text { Reward quality contribution } \\
\text { (Neilson, 2006) }\end{array}$ & & Human \\
\hline 6 & $\begin{array}{l}\text { Reward or incentives for contribution } \\
\text { (Hall \& Graham, 2004) } \\
\text { (Neilson, 2006) }\end{array}$ & & Human \\
\hline 7 & $\begin{array}{l}\text { Create simple interface for contribution } \\
\text { (Neilson, 2006) }\end{array}$ & $\begin{array}{l}\text { Technology usability } \\
\text { (Preece, 2000) }\end{array}$ & Technology \\
\hline 8 & $\begin{array}{l}\text { Discovery of information for personal benefit } \\
\text { (Hall \& Graham, 2004) }\end{array}$ & & Human \\
\hline 9 & $\begin{array}{l}\text { Response after contribution } \\
\text { (Joyce \& Kraut, 2006) }\end{array}$ & & Human \\
\hline
\end{tabular}




\begin{tabular}{|l|l|l|l|}
\hline 10 & Structure: Person to person (Network & Structure: Person to & Technology \\
& Generalised Exchange) & mediator (Group & \\
& (Sohn \& Leckenby, 2007) & Generalised Exchange) & \\
& & (Sohn \& Leckenby, & \\
& & 2007) & \\
\hline
\end{tabular}

Table 2. Enablers and barriers to participation in online or technology supported groups. Many of the above 'human' factors can be related to personality preferred behaviours, to be discussed next.

\section{Personality}

\section{A Brief History of the Five Factor Personality Research.}

Personality literature started to emerge from the discipline of psychology from about the 1930s onwards when William McDougall in 1932 identified five distinguishable 'factors' of personality. (Digman, 1990). While it was the researchers of the mid $20^{\text {th }}$ century who were able to further research and confirm this theory, McDougall displayed an early insight into the categorization and importance of personality traits on human behavior. The five factor model as it is known today did not emerge until Tupes and Christal (1961, cited in McCrae \& John, 1991) identified the same five re-occurring factors of personality traits in their research. The taxonomy of personality traits became known as the five factor model, or Big Five after multiple empirical studies verified this classification and taxonomy of personality (McCrae \& John, 1991).

Digman (1991) describes the five factor model as the "basic dimensions of personality", while McCrae and John (1991) summarize the five factor model as a hierarchical organization of personality traits across five basic dimensions. They argue that the model should prove useful both for individual assessment and for the elucidation of a number of topics of interest to personality psychologists. The five factor model has been robustly tested across languages and cultures and found to be a reliable model for personality (Schmitt, Allik, McCrae \& Benet-Martinez, 2007)

The five factor model has steadily become of interest to a range of researchers wider than personality psychologists, with research studies extending into the broad spectrum of human activity and behavior, from school attendance, blood donation, leadership behavior, 
sport participation and gambling, to name a few (Landers \& Lounsbury, 2006). Personality has also been researched in a number of related technology areas, such as; internet use, virtual team interaction, perception online, likeability and technology acceptance (Hamburger \& Ben-Artzi, 2000; Balthazard, Potter \& Warren, 2002; Rouse \& Haas, 2003; Byron \& Bladridge, 2007; Devaraj et. al. 2008).

The five factor model has proven to be a robust model of measurement and study for a range of human behaviors. McElroy, Hendrickson, Townsend, \& DeMarie (2007), summarize the key themes of the five factor model when they cite Costa and McCrae (1992) with the following:

"Agreeableness represents the tendency to be sympathetic, good-natured, cooperative, and forgiving. Highly agreeable people help others and expect help in return.

Conscientiousness represents the tendency to be self-disciplined, strongwilled, deliberate, and reliable. Conscientious people actively plan, organize, and carry out tasks.

Extraversion represents sociability, cheerfulness, and optimism. Extraverts seek out new opportunities and excitement.

Neuroticism represents a lack of psychological adjustment and emotional stability. Highly neurotic people tend to be fearful, sad, embarrassed, distrustful, and have difficulty managing stress.

Openness to experience represents one's curiosity and willingness to explore new ideas. Open individuals tend to devise novel ideas, hold unconventional values, and willingly question authority" (Costa and McCrae, 2000 in McElroy et.al. 2008)

\section{PERSONALITY TOOLS}

Researchers in the field of personality have developed tools to measure the five factor model of personality traits. The following is an overview and summary of some of main tools used in social science research and found in the literature reviewed.

Neo Personality Tool - NEO- Pi-R \& NEO - FFI 
Developed by Costa and McCrae (1992), this is considered to be the most validated of the five factor tools (John \& Srivastava, 1999). The NEO PI-R is a 240 item questionnaire, and has been commercially licensed. It measures not only the big five, but six facets of each of the big five. The NEO-FFI is a truncated 60 item version, of the 240 item version. This is also commercially controlled, and it only measures the big five not the six facets of each.

\section{Eysenck}

Eysenck and Eysenck (1985) developed a psychobiological model measuring levels of extraversion, neuroticism and psychoticism. Variations on the original model include; Eysenck Personality Inventory (EPI) (Eysenck \& Eysenck, 1975) and the Eysenck Personality Profiler (Eysenck and Eysenck, 1992). While not a strictly a five factor model tool, the Eysenck test does robustly measure two of the five traits (neuroticism and extraversion) (Amiel \& Sargent, 2004). These tests have been predominantly used in mass media research (Amiel \& Sargent 2004), and feature in research on internet use (Amiel \& Sargent, 2004; Hamburger et. al., 2000).

\section{Big Five Inventory - BFI}

The BFI was developed by John, Donahue, and Kentle, R. L. (1991). It is commonly used in research settings where subject time is at a premium. Due to its 44 question length, it takes participants about 5 minutes to complete. This tool has been published in a number or books and websites and is freely available for research purposes, provided appropriate referencing is given. It has also been compared with both the NEO-FFI and Trait Descriptive Adjectives (TDA), and proven to be a robust tool across many cultures and languages (Schmitt, et. al., 2007).

\section{Trait Descriptive Adjectives - TDA}

TDA was developed by Goldberg (1992). The research tool is 100 items long, and uses single word adjectives. This scale has been proven to have high consistent accuracy when compared with the longer NEO PI-R tool (John \& Srivastava, 1999).

\section{Personality and Behaviours Online}

Research studies on personality have been undertaken to identify how the big five personality traits impact and influence behavior in people. Many have been conducted specifically on personality in online behaviours, such as; internet use, virtual team 
interaction, perception online, likeability and technology acceptance (Hamburger \& BenArtzi, 2000; Balthazard et. al., 2002; Rouse \& Haas, 2003; Byron \& Bladridge, 2007; Devaraj et. al. 2008; Landers \& Lounsbury, 2006; Amiel \& Sargent, 2006; Tuten \& Bosnjak, 2001). Devaraj, Easley, and Crant (2008), showed there was a strong relationship between personality, online behavior and technology acceptance and use. Their research results supported the idea that individuals' who are high in agreeableness and conscientiousness traits are more likely to perceive usefulness of new technology, while individuals high in neurotic traits are less likely to perceive the usefulness of new technologies. Comparing this to Tuten and Bosnjak (2001), who found that individuals who are high in neurotic traits had lower levels of activity on the web in general. Tuten and Bosnjak (2001) also found a negative correlation between individuals who are high in neurotic traits and using the web to seek information. Swickert, Hittner, Harris and Herring (2002), found similar behaviours in their research when they found that in individuals high in neurotic traits were less likely to share information or play games online. Landers \& Lounsbury (2006), similarly to Tuten \& Bosnjak (2001) also found that personality traits could be indicative of the amount of time spent online, when they discovered that individuals high in both agreeableness and conscientiousness traits spent less time online. Importantly though they found that what time individuals high in conscientiousness spent online was more specific to a type of content; they had a preference for 'academic pursuits' compared with leisure activities online, i.e. time spent on information sharing sites, as opposed to entertainment sites. Evidently there are clear indicators of personality traits with the amount of time they spend and type of content they seek. This adds to the picture of how different personality types interact with different content, and possibly therefore which content they may participate in online communities.

Moving on to motivational factors, Amiel and Sargent (2006), sought to discover what motivational factors influenced particular personality types online. They found that individuals high in extraversion were motivated to participate by a desire to voice an opinion and were generally more willing to share information online, which is the opposite behaviour for individuals high in neurotic traits as discovered by Tuten and Bosnjak (2001) and Landers and Lounsbury (2006). Amiel and Sargent (2006) also found that individuals high in neuroticism participated online to find a sense of belonging. Both of their findings contribute to a picture of what type of 
personality is motivated by content type. Hamburger \& Ben-Artizi (2000) also looked at motivational factors in their research. They discovered that individuals high in extraversion were generally less likely to participate in chat and discussion sites. This could be seen to be disagreeing with Amiel and Sargent's (2006) finding that individuals high in extraversion traits are motivated by a willingness to share information and providing own opinion. However perhaps while these individuals generally spend less time online, when they do, this is how they are more likely to interact. Interestingly, Hamburger \& Ben-Artizi identified a gender split in behaviours online. Women high in neurotic traits were more likely to use the internet for participation in chat and discussion sites, by comparison to their male counterparts. This is the only research within the reviewed literature that identified a difference between particular personality traits and how they present in either men or women and technology and internet use. Swickert et. al. (2002) openly disagreed with Hamburger \& Ben-Artizi's findings, however as Swickert et. al. (2002) did not specifically look at gender differences on behaviours this is not too surprising as their sample of half and half women to men would expected cancel each other out. This view of Swickert et. al. (2002) is surprising given some of the research conducted on the impact of gender on personality traits by Ashmore (1990), Eysenck, \& Eysenck (1969), and Budaev (1999). They all write of how personality traits can be more prevalent in one gender over another. Specifically on this Budaev (1999) found that there is a marked difference between the spread of agreeable and neurotic traits between men and women. He found that both of these traits are more prevalent in women over men. His hypothesis is based on an evolutionary hypothesis that in human evolution, males have had to evolve to be more aggressive and dominant, than females and this dominance of behaviours has a close correspondence to personality traits, which he proved. (Budaev, 1999)

Similarly to Devaraj et. al. (2008), McElroy et. al. (2007) discovered that individuals high in openness were more likely and willing to try new technology. Their main finding however was that personality traits were a more accurate indicator of internet use than cognitive style. That being that the five factor model of personality was a better predictor of online behaviour than the way in which individuals process information and make judgments. Adding credence to the argument that personality type can be an indicator for behaviour online. Both Balthzard et. al. (2002) and Byron \& Baldridge (2007) looked more specifically at how different personality traits behave and perceive within computer mediated 
communication (CMC). Balthzard et. al. (2002) looked specifically at virtual teams, while Byron \& Baldridge (2007) reviewed email communication. Both found that personality traits influenced the level and perception of individuals using CMC. Balthzard et. al. (2002) found that individuals displaying extraversion traits were more responsible for promoting activity within virtual teams then their non-extravert counterparts. Byron \& Baldridge (2007), focused on perceived likeability, with individuals high in neurotic traits more likely to perceive sender liability as negative, while those displaying extraversion traits were more likely to be positive. Both of these studies are important to see how the different personality traits may perceive or interact with their online community members, as online community communication is a form of CMC.

Meshing the literature reviewed above in relation to specific behaviour and cross referencing it against the big five personality traits, a picture of online behaviour for each personality trait begins to emerge. The following table summarizes this:

\begin{tabular}{|l|l|l|}
\hline Personality Trait & Behavior & Author \\
\hline Agreeableness & Less time on internet in general. & Landers \& Lounsbury, 2006 \\
\hline & Less likely to use email. & Swickert et. al. 2002 \\
\hline Conscientiousness & $\begin{array}{l}\text { Less time on internet in general - } \\
\text { for what they see as unproductive } \\
\text { activities. }\end{array}$ & Landers \& Lounsbury, 2006 \\
\hline & $\begin{array}{l}\text { More likely to perceive usefulness } \\
\text { of new technology. }\end{array}$ & Devaraj et. al 2008 \\
\hline Extravert & $\begin{array}{l}\text { Less time on internet in general. } \\
\text { Motivated to contribute by a desire } \\
\text { to voice an opinion. }\end{array}$ & Amiel \& Sargent, 2006 \\
\hline & $\begin{array}{l}\text { Are more willing to share online. } \\
\text { chat and discussion sites. }\end{array}$ & Amiel \& Sargent, 2006 \\
\hline & $\begin{array}{l}\text { Less time on social services, such as } \\
\text { Hamburger \& Ben-Artizi 2000 }\end{array}$ & Lounsbury, 2006 \\
\hline
\end{tabular}




\begin{tabular}{|c|c|c|}
\hline & $\begin{array}{l}\text { Presence in virtual teams } \\
\text { encourages high levels of } \\
\text { interaction. }\end{array}$ & Balthazard et. al. (2002) \\
\hline & $\begin{array}{l}\text { Influenced perceived sender } \\
\text { likeability - positive. }\end{array}$ & Byron \& Baldridge (2007) \\
\hline \multirow[t]{6}{*}{ Neurotic } & $\begin{array}{l}\text { Use internet to find sense of } \\
\text { belonging. }\end{array}$ & Amiel \& Sargent, 2006 \\
\hline & $\begin{array}{l}\text { Less time online in general. } \\
\text { Information seeking - negative. }\end{array}$ & Tuten and Bosnjak, 2001 \\
\hline & $\begin{array}{l}\text { More likely to use internet for social } \\
\text { services, such as chat and discussion } \\
\text { group (Women). }\end{array}$ & Hamburger \& Ben-Artizi, 2000 \\
\hline & $\begin{array}{l}\text { Limit the amount of time playing } \\
\text { games and exchanging information. }\end{array}$ & Swickert et. al. 2002 \\
\hline & $\begin{array}{l}\text { Less likely to perceive usefulness of } \\
\text { new technology. }\end{array}$ & Devaraj et. al 2008 \\
\hline & $\begin{array}{l}\text { Influence perceived sender } \\
\text { likeability - negative. }\end{array}$ & Byron \& Baldridge (2007) \\
\hline Open Mindness & $\begin{array}{l}\text { More likely to be online and try new } \\
\text { technology. }\end{array}$ & McElroy et. al 2007 \\
\hline
\end{tabular}

Table 3: Personality trait and online behavior

Some conclusions that can be drawn from this table are:

- Agreeableness - Less time spent on the internet, but more accepting of new technology. This could be seen as contradictory, however, perceived usefulness does not equate to high use.

- Conscientiousness - Less time is spent on the internet for 'unproductive' or leisure pursuits, but is also more accepting of new technology thereby concluding that online activity that is perceived as productive to their work/study will be more readily perceived as useful and therefore will contribute to the level of use.

- Extravert - Less time is spent on the internet, but when contributions are made, people are motivated to voice an opinion and are willing to share. Less time is spent 
seeking social spaces online, and their presence in virtual teams encourage a high level of interaction. Extraverts are also more likely to perceive sender likeability as positive.

- Neurotic - Less time online in general, but when online, more likely to use the internet to find a sense of belonging: women in particular are more likely to spend time on discussion boards and chat rooms but are less likely to play online games and exchange information. They are less likely to perceive the usefulness of new technology are more likely to perceive sender likeability negatively.

- Openness - more likely to be online in general.

From the literature reviewed a number of statements can be made:

1. That there are human factors motivating contribution into online communities.

2. That personality does have an effect on behavior online.

3. That personality has an effect in communication online.

4. There has been no published research on what effect personality has on participation in online communities.

Web 2.0, by the definition provided above, identifies this new generation of user generated content on the web. For this reason there is a need to understand the effects (either) of personality on the motivations (or) personality has on motivation to participate online. There has been some research into how to contribution into online communities can be improved (Preece, 2000; Neilson, 2006), but, understanding how different personality types are motivated to participate could help understand the nature of online communities as they are, and perhaps alter the way in which online communities engage with their participants.

Matching up known motivating factors with known personality traits online, there is evidence to suggest that personality does influence the level and the type of participation in an online community. This can be achieved by using the same list of enablers of participation from Table 2, and cross referencing them with the known behaviours of specific personality traits from Table 3, to generate a picture of how personality may influence participation in online communities, in Table 4 below:

Enabler to Participation
Known Behaviour
Personality Trait 


\begin{tabular}{|c|c|c|c|}
\hline 1 & $\begin{array}{l}\text { Simplicity of information } \\
\text { and responses. } \\
\text { (Jones \& Ravid, 2004) } \\
\text { Create simple interface for } \\
\text { contribution. } \\
\text { (Neilson, 2006) }\end{array}$ & $\begin{array}{l}\text { More likely to perceive } \\
\text { usefulness of new technology } \\
\text { (Devaraj et. al. 2008) plus } \\
\text { 'cooperative and forgiving } \\
\text { nature'. (McElroy et. al. 2008) }\end{array}$ & $\begin{array}{l}\text { Agreeable (Inversely } \\
\text { related) }\end{array}$ \\
\hline 2 & $\begin{array}{l}\text { Friendship within } \\
\text { community members. } \\
\text { (Riddings \& Gefen, 2004) }\end{array}$ & $\begin{array}{l}\text { More willing to share online } \\
\text { (Amiel \& Sargent, 2006) and } \\
\text { Percieved sender likeability as } \\
\text { positive (Byron \& Baldridge, } \\
\text { 2007) plus 'sociability } \\
\text { nature'.(McElroy et. al., 2008) }\end{array}$ & Extraverts \\
\hline 3 & $\begin{array}{l}\text { Sense of belonging. } \\
\text { (Riddings \& Gefen, 2004) }\end{array}$ & $\begin{array}{l}\text { Use of internet to find sense of } \\
\text { belonging (Amiel \& Sargent, } \\
\text { 2006) and more likely to use } \\
\text { internet for social services } \\
\text { (women). (Ham burger \& Ben- } \\
\text { Artizi, 2000) }\end{array}$ & Neurotic \\
\hline 4 & $\begin{array}{l}\text { Reassurance of unique } \\
\text { contribution. } \\
\text { (Been et. al. 2004) } \\
\text { Reward quality } \\
\text { contribution. } \\
\text { (Neilson, 2006) }\end{array}$ & $\begin{array}{l}\text { Linked to sense of belonging } \\
\text { (Amiel \& Sargent, 2006) plus } \\
\text { emotionally unstable } \\
\text { nature.(McElroy at. al., 2008) }\end{array}$ & Neurotic \\
\hline 5 & $\begin{array}{l}\text { Reward or incentives for } \\
\text { contribution. } \\
\text { (Hall \& Graham, 2004) } \\
\text { (Neilson, 2006) }\end{array}$ & $\begin{array}{l}\text { Linked to sense of belonging } \\
\text { (Amiel \& Sargent, 2006) plus } \\
\text { emotionally unstable nature. } \\
\text { (McElroy at. al., 2008) }\end{array}$ & Neurotic \\
\hline
\end{tabular}




\begin{tabular}{|c|c|c|c|}
\hline 6 & $\begin{array}{l}\text { Discovery of information for } \\
\text { personal benefit. } \\
\text { (Hall \& Graham, 2004) }\end{array}$ & $\begin{array}{l}\text { Less time on internet in general - } \\
\text { for what they see as } \\
\text { unproductive activities. (Landers } \\
\text { \& Lounsbury, 2006) More likely } \\
\text { to perceive usefulness of new } \\
\text { technology. (Devaraj et. al., } \\
2008 \text { ) } \\
\text { Plus actively plan, organize, and } \\
\text { carry out tasks nature. (McElroy } \\
\text { et. al., 2008) }\end{array}$ & Conscientiousness \\
\hline 7 & $\begin{array}{l}\text { Response after } \\
\text { contribution. } \\
\text { (Joyce \& Kraut, 2006) }\end{array}$ & $\begin{array}{l}\text { Linked to sense of belonging } \\
\text { (Amiel \& Sargent, 2006) plus } \\
\text { emotionally unstable nature. } \\
\text { (McElroy at. al., 2008) }\end{array}$ & Neurotic \\
\hline
\end{tabular}

Table 4: Synthesis of enabling factors and personality trait

\section{Research PRopositions}

The following will draw on the literature review and the above summary table to draw out expected behaviours by particular personality traits in online communities.

Jones \& Ravid (2004) and Neilson (2006) observed that participation in an online community could be improved by the use of simple user interfaces. If individuals high in agreeableness are known to perceive usefulness of new technology (Devaraj et. al., 2008), and also display a cooperative and forgiving nature (McElroy et. al., 2008), then it could be concluded that individuals high in agreeableness traits will be more likely to persevere with more difficult online community interfaces. This conclusion will not be tested in this particular research due to the nature and scope of the project.

Riddings \& Gefen (2004) discovered that a sense of friendship within community members had a positive influence on participation in an online community. If individuals high in extraversion, as argued by Amiel \& Sargent (2006), are more likely to be motivated to share information, and are also more likely to perceive sender likeability positively (Byron \& 
Baldridge, 2007) it is concluded individuals high in extraversion may be motivated to contribute if they identify a sense of friendship within the community.

1. Expected Behaviours relating to individuals high in extraversion traits.

a) Individuals high in extraversion will be under-represented within participation in online community.

b) Individuals high in extraversion who contribute regularly will more likely identify a sense of friendship within the community.

Other enablers for participation are a sense of belonging (Amiel \& Sargent, 2006), reassurance of unique contribution (Beenen et. al., 2004), reward to quality contribution (Neilson, 2006), incentive for contribution (Hall \& Graham, 2004; Neilson, 2006), and response after contribution (Joyce \& Kraut, 2006). These enablers could all help develop a sense of belonging and/or a sense of community. Therefore these enablers could be more prevalent within individuals high in neurotic traits. If we accept that Riddings \& Gefen's (2004) 'sense of belonging' enabler is specific to individuals high in neurotic traits, and take note of Hamburger \& Ben-Artizi's (2000) discovery that women high in neurotic traits were more likely to use the internet for social services, or to join a group, it could be concluded that women high in neurotic traits are motivated to participate in online communities by a 'sense of belonging'. However, taking into consideration Tuten \& Bosnjak's (2001) research found that individuals high in neurotic traits spent less time online. This could be considered contradictory to the previous assertion that enablers to participation all feed into neurotic trait motivators, which would lead to the conclusion that individuals high in neurotic traits could be over represented in online community participation. Taking Tuten \& Bosnjak (2001) into consideration, it is therefore concluded that individuals high in neurotic traits will spend less time online, however when they are participating they will more likely be motivated by identifying a sense of belonging in the online community.

2. Expected Behaviours relating to individuals high neurotic traits.

a) Individuals high in neurotic traits will spend less time online.

b) When individuals high in neurotic traits participate online they will be more likely to be motivated to participate by a sense of belonging.

Hall \& Graham (2004) uncovered in their research that motivation to find out and contribute information for personal benefit is an enabler. While Landers \& Lounsbury (2006) discovered specifically individuals high in conscientiousness traits were less likely to spend time on 
'leisure activities' and more likely to seek information for personal benefit. Combine this with Devaraj et. al.'s (2008) assertion that individuals displaying traits high in conscientiousness were more likely to perceive usefulness of new technology. We can conclude that individuals displaying traits high in conscientiousness are more likely to contribute to online community that has a specific purpose for gathering useful information, rather than opinion sharing sites.

3. Expected Behaviour relating to individuals high in conscientiousness traits.

a) Individuals displaying high in conscientiousness traits will be more likely to be motivated by the sharing of useful information, than opinion sharing.

So far the conclusions have been based on singular presence of one of the five factor personality traits. While the literature reviewed did not uncover any combination of personality traits and online behaviour the following conclusions can be made.

If individuals who posted (long) questions were more likely to have those questions answered, then they were subsequently more likely to continue participating. Individuals displaying high in conscientiousness traits, would also be more likely to participate if they are identify a personal benefit, through either information seeking or asking questions of the community. Combined with what has been identified as the nature of individuals high in agreeableness, who are more likely to help others and expect help in return (McElroy, et.al., 2008). It therefore could be stated that individuals high in both conscientiousness and agreeableness could be an indicator of participation in information sharing sites, and will be motivated to find useful information.

If on the other hand we know that individuals high in neurotic traits are seeking a sense of belonging and participate more if their posts are responded to, then they may be more likely to be asking questions of the community. Also considering behaviours identified by individuals high in agreeableness, are more likely to help others and expect help in return (McElroy, et.al., 2008). It could therefore be stated that individuals high in both neurotic and agreeableness is an indicator of participation in asking and responding to questions, summarized in the diagram below;

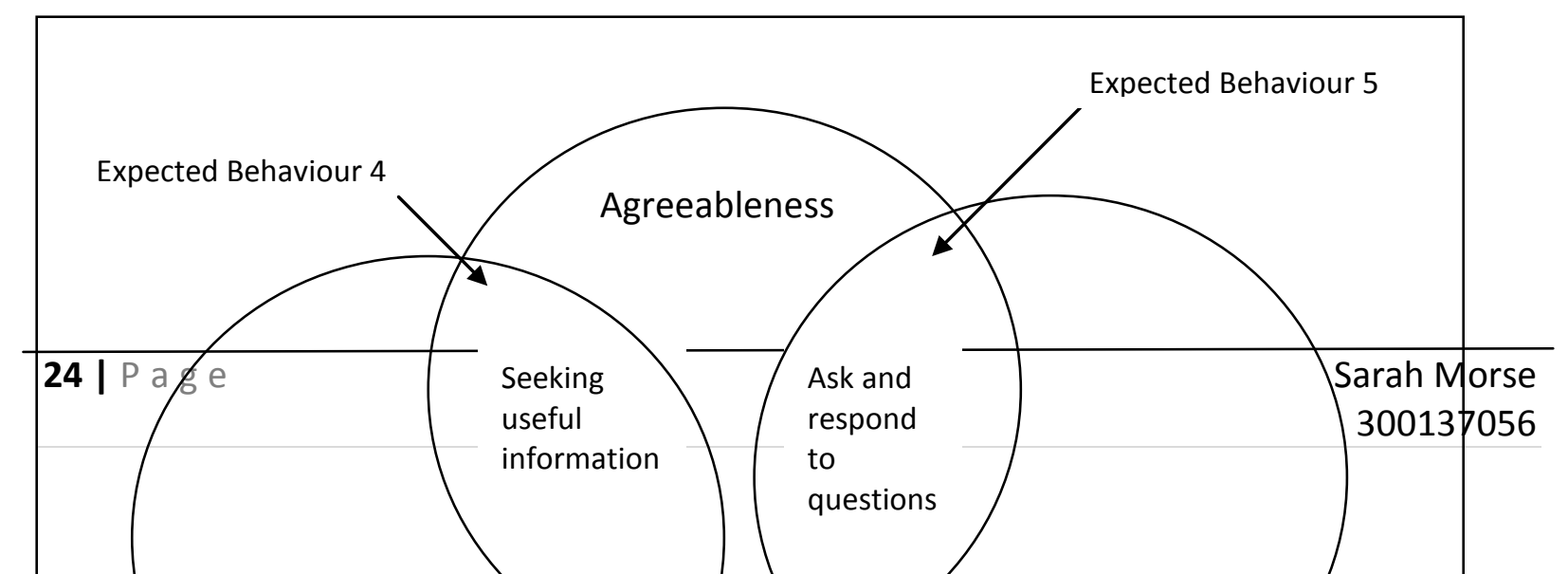


Figure 2. Overlap of personality traits for specific type of participation in an online community.

4. Expected Behaviour relating to individuals high in a combination of conscientiousness and agreeable traits.

a) Individuals high in both conscientiousness and agreeable traits will be motivated to participate by a desire to find useful information.

5. Expected Behaviour relating to individuals high in a combination of neurotic and agreeableness traits.

a) Individuals high in both neurotic and agreeableness traits will be motivated to participate by a desire to ask and respond to questions.

To be able to conclude from the above review literature if one particular trait maybe over represented in the small amount of participants in an online community is difficult. While many of the enablers fit in with expected behaviours of individuals displaying high in neurotic traits, taking Tuten and Bosnjak (2001) findings that individuals with neurotic traits spend less time online. However many of the other enablers to participate do fit in with the agreeableness trait, such as; asking and responding to questions. If we also take into consideration Budeav's (1991) assertion that agreeableness traits are higher in women, it could be concluded overall that a majority of individuals who participate regularly in an online community will be high in agreeableness and be women.

6. Expected Behaviour of those who participate regularly.

a) Individuals who participate regularly in an online community will be high in agreeableness and be women.

\section{Methodology}

This research was conducted using an online survey. It was split into three main parts. The first part of the survey collected demographic data and asked questions about an individual's 
participation levels and behaviours online. Participants will be asked about what they participate in, opinion or information gathering communities, their type of participation, if they ask questions or like to answer questions, and what makes them participate, sense of community and friendship.

The second section was a free text section that asked the respondents to state why in their own words they choose to participate or not to participate.

The third section was the 44 question BFI tool. This tool was developed by Srivastava and John (1999), and was chosen for two reasons. It is free to use for 'non-commercial' purposes, and is intended for research purpose. When it was compared with the much longer TDA (100 questions) and NEO-FFI (240 questions) the BFI (44 questions) provided pay off between short and robust results for the purpose of this paper (Srivastava \& John, 1991). The use of an online survey as a way of collecting the data was considered appropriate given the style of data being collected. The BFI is often given as a self reporting online test. (Srivastava \& John (1990). For a full version of the survey see the appendix B. The survey was distributed in a number of ways;

- Online social networks, Facebook, and word of mouth amongst friends and colleagues.

- Various e-mailing lists, fellow students, library lists and web industry lists.

The design of the survey for this research will be collected in a quantitative manner, but will also collect free text, for qualitative analysis, on the expectation that the quantitative analysis could provide further insight into the online participative behaviours of particular personality traits.

\section{BFI PERSONALITY TOOL}

The BFI tool provides the factor breakdown of which question indicates which personality traits. The BFI tool is provided with scoring instructions as to which questions contribute to which personality factors. The individual traits scores are measured by a comparison to population norms, and given a score of which percentile the individual falls into for that particular trait. Individuals who score over the $60 \%$ percentile are considered to be displaying behaviours high in that particular trait. (Srivastava \& John, 1991) 


\section{FINDINGS}

The online survey was open from $28^{\text {th }}$ August 2009 until the $27^{\text {th }}$ September 2009, with a total of 90 respondents. As the research is to investigate participation levels and types in online community, anybody who did indicate which online community they participated in or gave only a social networking site was discluded. This left a total of 82 respondents. The basic demographic break down of these respondents were; $68 \%$ were women, $66 \%$ were aged between 25-45 (exact breakdown below) with most being in full time employment. (81\%)

\begin{tabular}{|l|r|l|}
\hline Age & \% of Total & Numbers \\
\hline $21-25$ & $6.10 \%$ & $(\mathrm{n}=5)$ \\
\hline $26-30$ & $14.63 \%$ & $(\mathrm{n}=12)$ \\
\hline $31-35$ & $20.73 \%$ & $(\mathrm{n}=17)$ \\
\hline $36-40$ & $18.29 \%$ & $(\mathrm{n}=15)$ \\
\hline $41-45$ & $13.41 \%$ & $(\mathrm{n}=11)$ \\
\hline $46-50$ & $13.41 \%$ & $(\mathrm{n}=11)$ \\
\hline $51-55$ & $7.32 \%$ & $(\mathrm{n}=6)$ \\
\hline $56-60$ & $3.66 \%$ & $(\mathrm{n}=3)$ \\
\hline $61-65$ & $2.44 \%$ & $(\mathrm{n}=2)$ \\
\hline Total & & $\mathrm{n}=\mathbf{8 2}$ \\
\hline
\end{tabular}

Table 5. Full age breakdown of collected sample.

\section{LEVEL OF ONLINE COMMUNITY PARTICIPATION}

The respondents were asked how often they visited and how often they participated in online community. The survey was specifically sent out and invited individuals who have high levels of visiting and participation. The results on how many of them participated actively in online community activity was skewed high, this result was expected.

82.93\% ( $n=68$ ) visited an online community sites regularly. (At least once a week) While $51.22 \%(n=43)$ stated that they participated regularly (at least once a week) in an online community.

\section{MOTIVATING FACTORS TO PARTICIPATE}

The respondents were asked how much the following statements they agreed with or disagreed in regard to how they participated online.

- I like to ask questions

- I feel a sense of belonging

- I feel a sense of friendship

- I like to give my opinion 
- I like to provide information

- I feel I get useful information

From the total sample the below is the percentage of respondents who agreed or strongly agreed with the participant motivation statements.

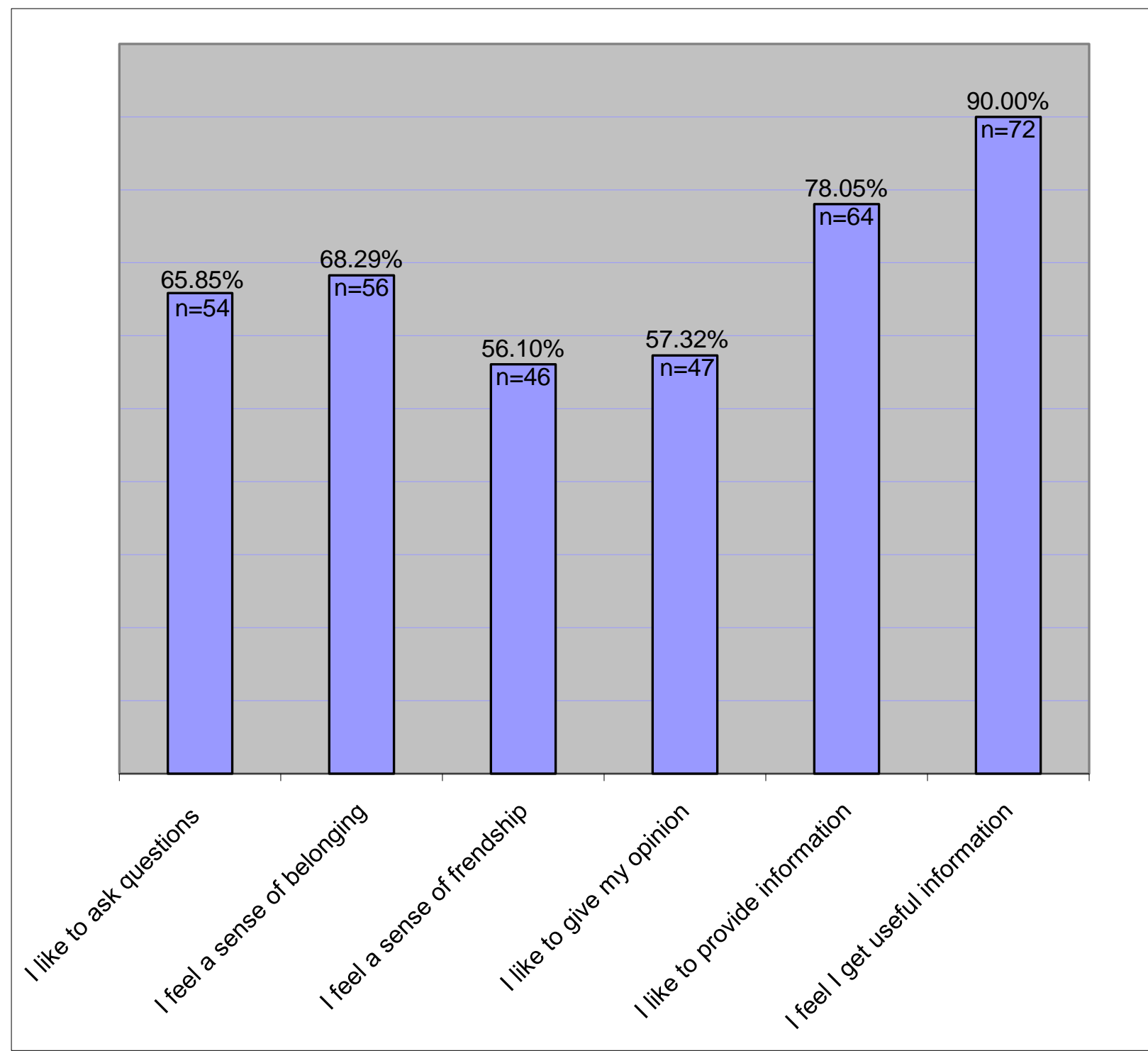

community discussed above. Interestingly the lowest scorıng statement "I teel a sense of friendship" is an interesting finding, at a score of $56.10 \%(n=46)$ just under half of all respondents did not agree, or had no feeling either way. This could imply just under half of all people who use online communities do not do so for the social friendship aspect.

\section{PERSONALITY PROFILE OF RESPONDENTS}

The BFI measures personality across the five factor model. The five factors represent a continuum of personality traits. Individuals scoring high in a particular trait are those that are higher than the medium spectrum across the entire population. Based on the scores that 
have been normalized by the creators of the BFI (John et.al., 1991) the profile of the sample collected for this research paper are as follows.

\begin{tabular}{|l|l|}
\hline Trait & $\begin{array}{l}\text { Percentage of total sample }(n=82) \text { scoring } \\
\text { 'high' in this trait* }\end{array}$ \\
\hline Extraversion & $23.17 \%(n=19)$ \\
\hline Neuroticism & $13.31 \%(n=11)$ \\
\hline Conscientiousness & $47.56 \%(n=39)$ \\
\hline Agreeableness & $45.12 \%(n=37)$ \\
\hline Openness & $43.90 \%(n=36)$ \\
\hline
\end{tabular}

Table 7. Percent of respondents who scored high in particular personality traits.

* Any particular individual may present high in any number of individual traits, which means some individuals may present with no particular trait, while others may present with as many as four or all five.

It would be expected in any sample that the traits would come out between the $45-55 \%$ mark. This sample is skewed and is under-represented in both Extraversion and Neurotic traits.

\section{QUALITATIVE RESULTS}

The respondents were asked to comment on reasons why and reasons why they would not participate in an online community. The responses were coded into over arching themes, these are displayed in the following table;

\begin{tabular}{|c|c|}
\hline Motivating factors & De-motivating Factors \\
\hline $\begin{array}{l}\text { Knowledge sharing }(n=26) \\
\text { - Wanting to contribute }(n=3) \\
\text { agreeableness }(n=6) \\
(\text { Total } n=37)\end{array}$ & $\begin{array}{l}\text { Perceived value of contribution }(n=4) \\
\text { - Nothing to say }(n=1) \\
\text { - Nothing unique to contribute }(n=10) \\
\text { (Total } n=21)\end{array}$ \\
\hline $\begin{array}{l}\text { Information Seeking }(n=17) \\
-\quad \text { Learning }(n=7) \\
(\text { Total } n=24)\end{array}$ & $\begin{array}{l}\text { Quality/Nature of current posts }(n=5) \\
80 \% \text { high in conscientiousness }(n=4)\end{array}$ \\
\hline $\begin{aligned} \text { Sense of Community }(n=7) \\
\text { - } \\
\text { - Support }(n=1) \\
\text { Connectedness }(n=2)\end{aligned}$ & Not enough time $(n=8)$ \\
\hline
\end{tabular}




\begin{tabular}{|l|l|}
\hline$($ Total $n=10)$ & \\
\hline Opinion giving $(n=5)$ & Privacy $(n=2)$ \\
\hline Friendship $(n=4)$ & Technical $(n=2)$ \\
\hline Have to for work $(n=3)$ & Response to their post $(n=6)$ \\
\hline Sense of belonging $(n=3)$ & Gender $(n=2)$ \\
\hline
\end{tabular}

Table 6. Codes from qualitative analysis of free text fields, with numbers of entries.

Many of these codes match up with the motivational factors asked about within the survey; however some important nuances start to appear. Most of the survey respondents agreed that participation in an online community is to either share their own knowledge or to find out new information. The qualitative analysis has been able to dig deeper on factors for participation, most had no correlation to personality traits except for the two noted in the table above.

$75 \%$ of those individuals who stated they contribute in online community to 'help others' were high in agreeableness. Of those individuals who stated that they did not contribute because of the low quality of the other posts or the tone of the conversation $80 \%$ were high in conscientiousness traits.

Below are some examples of the conscientious individuals who spoke of wanting to impart information or knowledge, clearly framing it within a motivation to 'help others'.

"I like to impart knowledge that I have on particular subjects. If I have information that will help another member then it is good to share and help others."

(Male, Age 31-35, extravert, agreeable, conscientiousness, openness traits all present)

"I like to help others out if I know the answer to their questions."

(Female, Age 31-35, agreeable and conscientiousness traits both present)

"(I) Like helping people with topics that I know about."

(Male, Age 31-35, agreeable and openness trait both present)

While those that described a motivation to find out more information often described their 'want to learn'.

"I also enjoy learning from them, whether it is how they have reacted or coped with a certain issue."

(Female, Age 31-35, extravert trait present)

The question 'why do you not actively participate?' was the only opportunity within the survey for the respondents to identify de-motivational factors for participation. Given the literature reviewed and what is known about individuals high in neurotic traits, it may be expected that they may be over represented here. However with the particularly low 
number of respondents high in neurotic traits this was not found. The following is a quote from one individual high in neurotic traits.

"If it's a generic topic with a lot of contributions, I don't usually feel that I would

have anything new/of particular value to say."

(Male, Age 26-30, extravert and neurotic traits present)

Response to posts was identified in the literature by Joyce and Kraut (2006), and has been identified by the respondents. There was no correlation between this factor and personality traits.

"I like to answer people's questions when I can, although, I don't post that

often because I often feel like my posts are ignored"

(Female, Age 21-25, agreeable, conscientious and openness traits all present)

Some of the de-motivational factors that are not identified in the literature reviewed, but were uncovered in the qualitative analysis, are of more of a personal reason, for example lack of confidence in their contribution.

"Feel a bit intimidated by it, most contributors appear to be at senior level, management."

(Female, Age 36-40, openness trait only present)

The quality and nature of the existing posts is another factor that was not identified in the literature reviewed and appeared in the qualitative analysis. Overwhelmingly those that did identify this factor $(80 \%)$ were high in conscientiousness traits.

"I don't post anything in the comments section of youtube because its full of idiot."

(Male, Age 26-30, conscientious trait only present)

"There's one community which is fairly brutal and intimidating. You get quite a bit of

abuse for being only mildly off-topic. Flame wars erupt very easily in that

community."

(Female, Age 41-45, conscientious and openness trait present)

"It can get quite bitchy and opinionated at times and I can't be bothered with that!"

(Female, Age 31-35, agreeableness and conscientiousness trait present)

\section{TESTING EXPECTED BEHAVIOURS}

1. Expected Behaviours relating to individuals high in extraversion traits

a) Individuals high in extraversion will be under-represented within participation in online community.

b) Individuals high in extraversion who contribute regularly will more likely identify a sense of friendship within the community.

Extraversion traits were underrepresented in active participation online, making up only

$23.17 \%(n=19)$ of the total sample. Of the individuals displaying extraversion traits who participated regularly $(n=11)$ all agreed or strongly agreed that they found a sense of friendship in online communities. Therefore both expected behaviours relating to extraversion traits were found. However when the sample is split between men and women 
it is discovered that men high in extraversion $(n=4)$ are less likely to identify the sense of friendship $(25 \%, n=1)$. So it could be concluded that expected behaviour $1 \mathrm{~b}$ is more likely to be true for women, rather than men who are high in extraversion. See Appendix C for a breakdown of the motivators split between the genders.

2. Expected Behaviours relating to individuals high in neurotic traits.

a) Individuals high in neurotic traits will spend less time online.

b) When individuals high in neurotic traits to participate they will be more likely to be motivated to participate by a sense of belonging.

Overall there was under representation of neurotic traits within participation in online community, making up only $13.31 \%(n=11)$ of the total sample. Of the individuals displaying neurotic traits who participated regularly $(n=4), 75 \%(n=3)$ of them agreed or strongly agreed that they did so to find a sense of belonging. Therefore both expected behaviours relating to neurotic traits were displayed.

3. Expected Behaviour relating to individuals high in conscientiousness traits.

a) Individuals high in conscientiousness traits will be more likely to be motivated by the sharing of useful information, rather than opinion sharing.

Of the individuals displaying high in conscientiousness traits who participated regularly $(n=14) 85 \%(n=12)$, do so to find useful information. While of the individuals displaying high in conscientiousness traits who participated regularly $(n=14) 71 \%$ were motivated by sharing opinions. However as both of these results are lower for the finding useful information (90\%) and higher for opinion (57.56\%) it has to be concluded that this behaviour for conscientiousness traits was not found for the wider sample. However when the sample is split between men and women, we can see that women who participate regularly who are high in conscientiousness traits $(n=29)$, only $41.38 \%(n=12)$ were motivated to participate by opinion sharing. This is much lower than the wider sample of $57.56 \%$. Their motivation to participate by finding useful information was almost the same as the wider sample at $86.21 \%(n=25)$. So we could conclude that women high in conscientiousness traits are more likely to exhibit this expected behaviour. See Appendix C for a breakdown of the motivators split between the genders.

4. Expected Behaviour relating to combination of individuals high in both conscientiousness and agreeable traits. 
b) Individuals displaying high in both conscientiousness and agreeable traits will be motivated to participate by a desire to find useful information

Of the individuals displaying high in both traits $71 \%(n=7)$, agreed or strongly agreed that they did so to find useful information. As this figure is lower than the wider sample figure for this motivator it is concluded that this expected behaviour was not found.

5. Expected Behaviour relating to combination of individuals high in both neurotic and agreeableness traits.

a) Individuals displaying high in both neurotic and agreeableness traits will be motivated to participate by a desire to ask and respond to questions.

Due to the low representation of individuals presenting with the combination of both of these traits this behaviour could not be observed either way.

6. Expected Behaviour of those you participate regularly.

a) Individuals who participate regularly in an online community will be high in agreeableness and be women.

The sample as a whole was $68 \%$ women, which in part supports this expected behaviour. However of the women who participated regularly $(n=28), 46 \%$ of them displayed high in agreeableness $(n=13)$. Due to the weighting of women to men over the total sample $(68 \%$ women to $32 \%$ men) we can say that this behaviour was not found, as the wider sample had a distribution of $45.12 \%(n=37)$ of individuals high in agreeableness, they are almost the same.

To summarize the above table;

Women who are high in;

- Extraversion traits are less likely to ask questions.

- Neurotic traits are less likely to ask questions, or seek friendship.

- Agreeable traits are less likely to provide opinion.

- Conscientiousness traits are less likely to seek friendship or provide opinion.

Men who are high in;

- Extraversion traits are less likely to seek friendship.

- Neurotic traits are less likely to provide opinion, or to provide information.

- Agreeable traits are less likely to seek friendship. 
- Conscientiousness traits are less likely to find a sense of belonging or to seek friendship

- Openness traits are less likely to ask questions.

\section{DISCUSSION}

The basic demographic data indicates some interesting things about the sample. The survey was specifically sent out to and asked for individuals who participated regularly in online communities. This is reflected in the amount of respondents who stated they participated regularly (51.22\%). This figure is twice as high as research conducted from a more representative general populous sample, such as the World Internet Project (Bell, Crothers, Goodwin, Kripalani, Sherman, and Smith, P. 2007). Their study found that only just over $25 \%$ of all people were engaged in contributing content online.

The results of the motivating factors from the survey were in line with what the literature review uncovered. It was useful to see that all the questions asked were mostly agreed or strongly agreed to by the respondents. Reinforcing the research and practioner literature reviewed. Sense of friendship was the lowest scoring one at $56.10 \%(n=46)$. This could be because it was individuals high in extraversion who identified with this motivating factor and these individuals are generally less likely to be active in online communities. So there for a lower score. This is still relevant motivating factor, as individuals high in extraversion have been proven to be beneficial in generating activity in CMC (Balthazard, et. al., 2002). So could therefore be considered valuable participants, in the way that they encourage other users to take part.

The qualitative analysis of other motivational factors uncovered some interesting themes that had not been identified in the literature reviewed. The most specific finding from this analysis in relation to personality traits was that individuals high in agreeableness identified with a motivation to 'help others'. This is not a surprising discovery given that this is one of the identifying markers for the agreeableness trait (Costa and McCrae, 2000 in McElroy et.al. 2008). The qualitative analysis also gave some interesting insight into de-motivational factors, or barriers to participation. The most interesting finding here was the discovery that 
$80 \%$ of those individuals who identified that the quality and nature of the existing posts was a barrier to their participation were high in conscientiousness. This can be explained by what is known of conscientiousness traits, that they are self disciplined, deliberate and reliable (Costa and McCrae, 2000 in McElroy et.al. 2008). In opposite it is logical to assume that they then would have little time for 'time wasters'. This study also found that individuals high in conscientiousness traits were mostly motivated by a desire to find useful information, therefore it stands to reason that if useful information is not to be had then they would not bother participating. Moderating content to improve participation levels then becomes important.

The big five model and specifically the BFI tool used for this study has proven to be a robust tool for measuring personality factors across many cultures and languages (Schmitt, et. al., 2007). There is an acceptance that there is a link between the range of personality traits and different cultures, however in relation to this study the sample did not ask country of origin so could not begin to take this issue into account. What is evident from the results is the differences between the genders of the same personality trait. None of the literature found was able to explain why the different genders with the same personality trait will have different motivators to participation. Although this could be further complicated by combinations of traits, as per Budaev (1999) and that men and women may have different presentations of combinations of traits. Given the size of the sample and scope of this project the results do not provide enough data to explore this any further. However this could be an area for more in-depth research.

\section{CONCLUSIONS}

This research project sought out to find out if personality traits influence the type and level of participation in online communities. Overall this research has proven this statement. However, the assertion was one particular personality trait dominating the relatively low amount of active participants in any one community has proven to be untrue. What can be said is that personality traits are indicative of what type of participation they prefer (extraversion traits and sense of friendship, neurotic traits and sense of belonging, 
conscientiousness traits and quality/nature of posts, and agreeableness traits and wanting to 'help others').

Therefore if a particular online community has a certain type or style of participation activity then this could mean that there are over representatives of individuals high in particular personality traits. As this survey went out to individuals who are involved in many online communities it is hard to say for sure, further more in-depth research into one type of community would be required to fully explore this assertion.

\section{LIMITATIONS TO THIS PROJECT AND SUGGESTIONS FOR FURTHER RESEARCH.}

The scope of this research project could not go into the intricacies of personality research in much depth. However, what the results of this study do prove is that there something worthy of further investigation. Knowing that personality types do influence type and level of participation in online community it would be beneficial to dig deeper, perhaps by studying a larger amount of participants of one particular online community.

The sample size was too small to make any solid conclusions, but was enough to offer a connection between the personality traits and online participation. The cross over between online community and social networking also presented an interesting challenge for the researcher, with many participants discussing things in regard to social networking sites such as Facebook. When online community was being defined for this project there was a clear delineation between the two concepts, however in reality individuals do not always appreciate this difference. Focusing on a specific online community may have got around this issue. What this research has highlighted with the finding is the growing importance of online community in people's lives.

\section{IMPLICATIONS FOR PRACTICE}

This study has confirmed many of the assertions made in the burgeoning literature on participation in online community, by showing that there are many enablers and barriers to participation, and that many of them are linked up to specific personality behaviours. When personality traits influence the level and type of participation then this could have implications communities if they are to be seen to be seen representatives of the wider community; as in the case with e-government consultation sites, or with consumer feedback sites. It could however, be argued that this is no different to any participation in any (face to face) community. Online communities can only, therefore provide another avenue for 
engagement, but not necessarily replace more traditional means of government and consumer consultation. The main finding relevant to practioners is that of the quality and nature of posts being a barrier for participation, and a careful reminder to anyone considering using an online community to bear in mind the moderation and maintenance aspect to the user generated content. Another relevant finding is generally how the different personality traits will engage in different content activities, preferring some over others. For the practioner this means thinking about the nature of the user generated content and ensuring there are options for engagement to achieve a balanced view and perhaps increased participation levels. 


\section{Participant Information Sheet for a Study of Personality Traits and Participation level and type in Online Community}

Researcher: Sarah Morse: School of Information Management, Victoria University of Wellington

I am a Masters student in Information Management at Victoria University of Wellington. As part of this degree I am undertaking a research project leading to a research report. The project I am undertaking is to find out if personality traits influence the level and type of participation in online communities.

For the purpose of this research I am defining an online community as one that requires individuals to sign up to, it and which exists in an online environment, either via email or on the internet. Activity in social networking sites (facebook, bebo, twitter) is not considered to be participation in an online community. Activity, either contributing content, asking questions, answering questions, placing statements is considered participation. Someone who only reads (lurk) and does not actively contribute contents is still considered to be part of an online community, but their level of participation is considered less.

The benefits of this research are to find out more about the people who are actively contributing content. Research shows us that, in general, only $1 \%$ of any online community will actively participate, contributing most of the content to the community. The aim of this research is to find out more about what personality type those people may be.

This research has been approved by the School of Information Management's Human Ethics Committee.

If you agree to participate you will be asked to fill out an online survey that will assess your personality traits using the Five Factor Model of personality, the level and type of participation that you may have in an online community, and other demographic data that may influence your ability to participate, such as, internet connection, childcare responsibility and employment status.

It is envisaged that the questionnaire will take less than 10 minutes to complete.

No information collected will be used to identify individual participants. For this reason no individual feedback can be offered to participants about their personality profile, links will be provided at the end of the survey to other online personality testing for those that wish to learn more about their personality.

Responses collected will form the basis of my research project and will be put into a written report on an anonymous basis. It will not be possible for you to be identified personally. All material collected will be kept confidential. All survey data will be held in password protected files and be destroyed two years after the end of the project. No other person besides me and my supervisor, Professor Rowena Cullen, will see the results to the survey.

The report will be submitted for marking to the School of Information Management and may be deposited in the University Library. It is intended that one or more articles may be submitted for publication in scholarly journals.

If you have any questions or would like to receive further information about the project, please contact me at sarah.morse@vuw.ac.nz or my supervisor, Professor 
Rowena Cullen, rowen.cullen@vuw.ac.nz at the School of Information Management, Victoria University of Wellington, P O Box 600, Wellington, 044635788

I accept - please continue on to complete the survey

No thanks, l've decided not to take part - close the window 


\section{APPENDIX B}

Survey

Page 1 of 2

\section{7i VICTORLA}

Personality and Participation in Online Community.

This is a research survey to find out if personality type influences the type and level of participation in online community. Please complete the survey and submit.
1. What is your age bracket?
Under 15
16-20
21-25
26-30
31-35
$36-40$
$41-45$
46-50
51-55
$56-60$
$61-65$
Oover 65

\section{What is your gender?}
Male
Female

\section{What is your employment status?}
Part-time
Full-time
Student
Stay at home parent
Unemployed/looking for work
Retired
4. Do you have children living who live with you at least half of the time?
Yes
No

5. If you do have children living with you, how old are they?

under 5 


$$
\begin{aligned}
& \text { 6-15 } \\
& \text { over } 16
\end{aligned}
$$

6. Where do you access the internet from? Select as many as appropriate.

$\square$ Home
$\square$ Work
$\square$ Cafe
$\square$ Other?

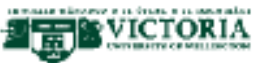


7.

In which online communities do you actively particpate by contributing or read content? Please list.

Think about the community in which you most actively participate to answer the rest of this survey.

8.

Regularly - at least once a week

Occassionally - about once a month

hardly ever - a few

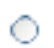

How often do you visit this community? times a year

\section{9.}

Regularly - at Occassionally - I only read, and never least once a about once a month or hardly ever week participate

How much you participate by submitting content, replying or commenting posts do you do in this community?

C

0

0

10. How much do you agree or disagree with the following phrases when describing your participation in the online community.

I like to ask questions of people in the community

I feel a sense of belonging to the community

I feel a sense of friendship with people in the community

I like to give my opinion

I like to provide information

I feel I get useful information from

$\begin{array}{ccccc}\begin{array}{c}\text { Disagree } \\ \text { strongly }\end{array} & \begin{array}{c}\text { Disagree a } \\ \text { little }\end{array} & \begin{array}{c}\text { Neither disagree } \\ \text { or agree }\end{array} & \begin{array}{c}\text { Agree a } \\ \text { little }\end{array} & \begin{array}{c}\text { Agree } \\ \text { Strongly }\end{array} \\ 0 & 0 & 0 & 0 & 0 \\ 0 & 0 & 0 & 0 & 0 \\ 0 & 0 & 0 & 0 & 0 \\ 0 & 0 & 0 & 0 & 0 \\ 0 & 0 & 0 & 0 & 0 \\ & 0 & 0 & 0 & 0\end{array}$

http://surveys.vuw.ac.nz/fs.aspx?surveyid=1241bc55a714ddca74e48531a93b017 
the community

11. If you participate regulary (atleast once a month) in an online community by contributing content, what would you say are the reasons?

12. If you only read/lurk in an online community, why do you not actively participate? 


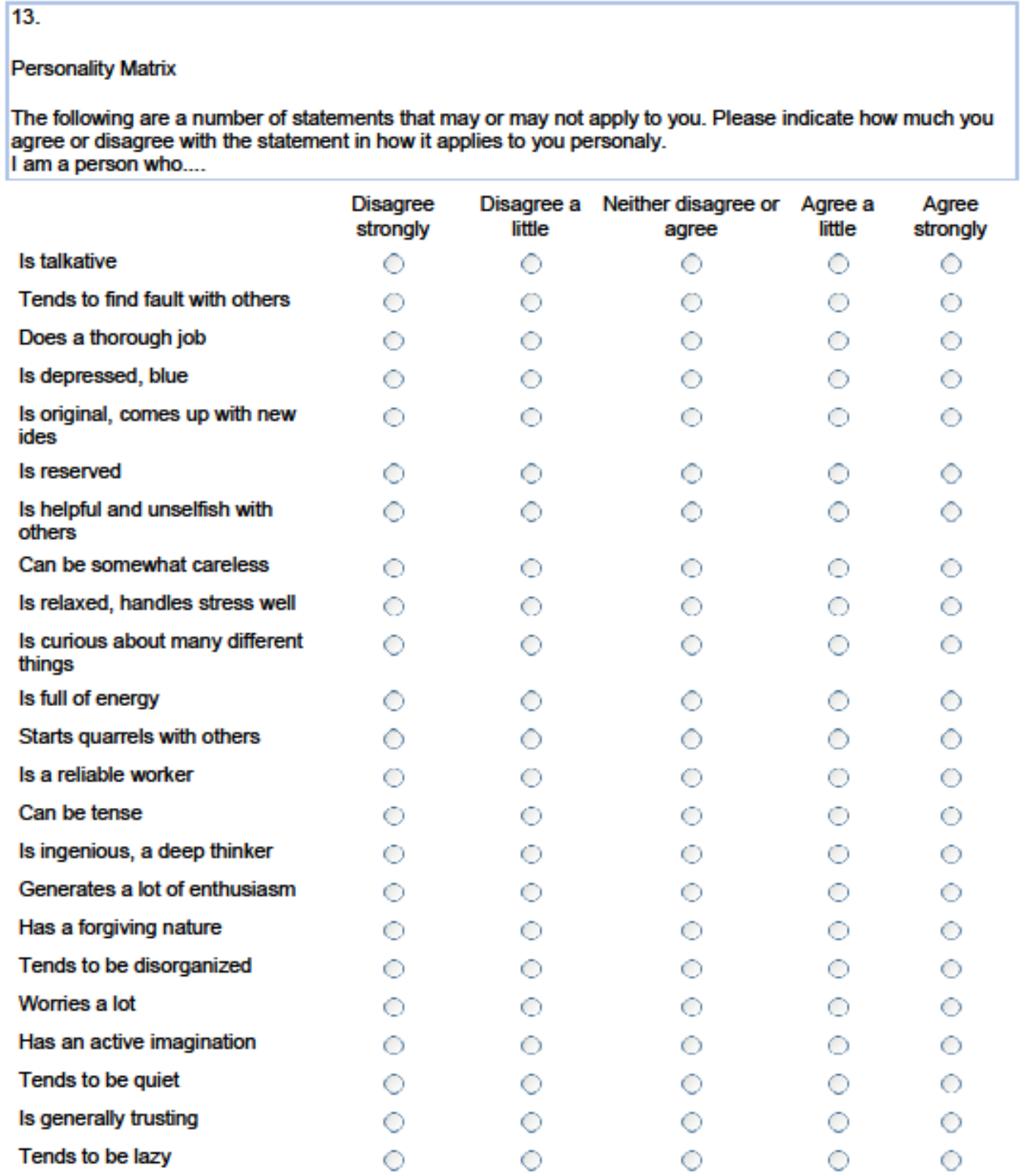




Is emotionally stable, not easily
upset
Is inventive
Has an assertive personality
$\begin{aligned} & \text { Can be cold and aloof } \\ & \text { Perseveres until the task is }\end{aligned}$
finished
Can be moody
$\begin{aligned} & \text { Values artistic, aesthetic } \\ & \text { experiences }\end{aligned}$




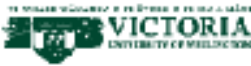

Thank you for completing my survey.

As this is a completely anonmous survey I am unable to provide individual feedback on your personality breakdown. If you are interested to learn more about your personality using the Five Factor Model, then please follow one of the following links.

The Personality Project - http-//test.personality-project.orq/

or

http://www. outofservice.com/biqfivel - the same test as included in this survey.

If you would like to recieve a copy of the summary report or have any further questions about my research please do not hesitate to contact me at sarah.morse@vuw.ac.nz 


\section{APPENDIX C}

BREAKDOWN OF PARTICIPATION MOTIVATORS SPLIT ACROSS THE GENDERS.

\begin{tabular}{|c|c|c|c|c|c|c|c|c|c|c|}
\hline & \multicolumn{2}{|c|}{ Extraversion } & \multicolumn{2}{|c|}{ Neurotic } & \multicolumn{2}{|c|}{ Agreeableness } & \multicolumn{2}{|c|}{ Conscientiousness } & \multicolumn{2}{|c|}{ Open } \\
\hline & $\begin{array}{c}\% \text { of total } \\
\text { sample }\end{array}$ & $\begin{array}{c}\% \text { of all } \\
\text { extraverts }\end{array}$ & $\begin{array}{c}\% \text { of total } \\
\text { sample }\end{array}$ & $\begin{array}{l}\% \text { of all } \\
\text { Neurotics }\end{array}$ & $\begin{array}{c}\% \text { of total } \\
\text { sample }\end{array}$ & $\begin{array}{c}\% \text { of all } \\
\text { Agreeableness }\end{array}$ & $\begin{array}{c}\% \text { of total } \\
\text { sample }\end{array}$ & $\begin{array}{c}\% \text { of all } \\
\text { Conscientiousness }\end{array}$ & $\begin{array}{c}\% \text { of total } \\
\text { sample }\end{array}$ & $\begin{array}{l}\% \text { of all } \\
\text { Openness }\end{array}$ \\
\hline $\begin{array}{l}\text { Women } \\
n=57\end{array}$ & $26.32 \%$ & $\mathrm{n}=15$ & $17.54 \%$ & $n=10$ & $40.35 \%$ & $n=23$ & $50.88 \%$ & $n=29$ & $43.86 \%$ & $n=-25$ \\
\hline 1 like to ask questions & $19.30 \%$ & $73.33 \%$ & $8.77 \%$ & $50.00 \%$ & $26.32 \%$ & $65.22 \%$ & $29.82 \%$ & $58.62 \%$ & $31.58 \%$ & $72.00 \%$ \\
\hline I feel a sense of belonging & $26.32 \%$ & $73.33 \%$ & $26.32 \%$ & $60.00 \%$ & $26.32 \%$ & $69.57 \%$ & $26.32 \%$ & $62.07 \%$ & $26.32 \%$ & $80.00 \%$ \\
\hline I feel a sense of friendship & $21.05 \%$ & $80.00 \%$ & $8.77 \%$ & $50.00 \%$ & $24.56 \%$ & $60.87 \%$ & $26.32 \%$ & $51.72 \%$ & $26.32 \%$ & $60.00 \%$ \\
\hline I like to give my opinion & $15.79 \%$ & $60.00 \%$ & $12.28 \%$ & $70.00 \%$ & $22.81 \%$ & $56.52 \%$ & $21.05 \%$ & $41.38 \%$ & $29.82 \%$ & $68.00 \%$ \\
\hline I like to provide information & $24.56 \%$ & $93.33 \%$ & $12.28 \%$ & $70.00 \%$ & $29.82 \%$ & $73.91 \%$ & $35.09 \%$ & $68.97 \%$ & $35.09 \%$ & $80.00 \%$ \\
\hline I feel I get useful information & $21.05 \%$ & $80.00 \%$ & $14.04 \%$ & $80.00 \%$ & $35.09 \%$ & $62.50 \%$ & $43.86 \%$ & $86.21 \%$ & $40.35 \%$ & $92.00 \%$ \\
\hline
\end{tabular}

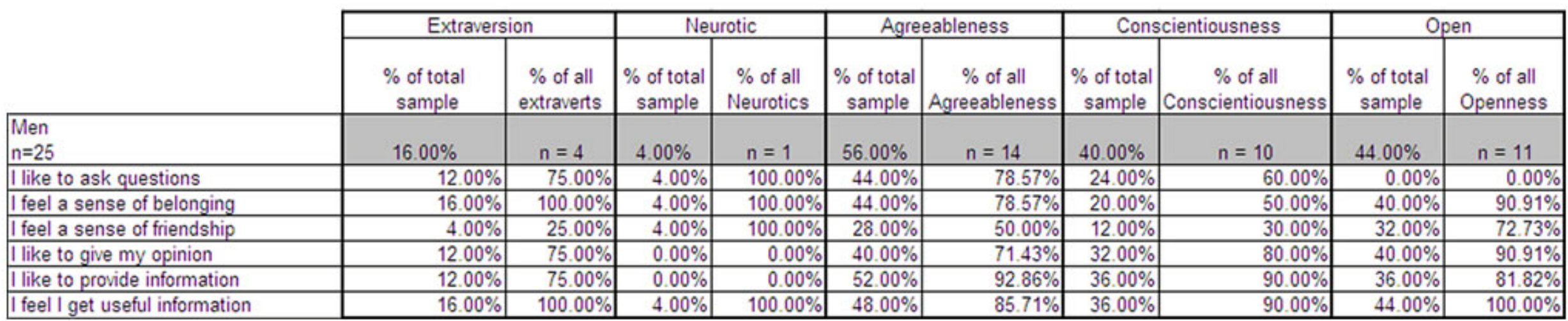




\section{REFERENCES}

Adair, J. (2006). Leadership and Motivation. London: Kogan.

Amiel, T. \& Sargent, S. L. (2004). Individual differences in internet usage motives. Computers in Human Behavior. 20, 711-726.

Anderson, C. (2008). The long tail: why the future of business is selling less of more. New York: Hyperion.

Ashmore, R. D. (1990). Sex, gender and the individual. In L. A. Pervin (ed)., (1990) Handbook of personality: Theory and research. New York: Guilford Press.

Balthazard, P., Potter, R. E., \& Warren, J. (2004). Expertise, extraversion and group interaction styles as performance indicators in virtual teams. Database for Advances in Information Systems, 35(1), 41-64.

BBC. (2007). NZ police let public write laws. Retrieved October 8th 2008 from http://news.bbc.co.uk/2/hi/asia-pacific/7015024.stm

Beenen, G., Ling, K., Wang, X., Chang, K. and Frankowski, D. (2004, Nov 6-10). Using Social Psychology to Motivate Contributions to Online Communities. Paper presented at ACM Conference on Computer Supported Cooperative Work. Chicago, Illinois, USA.

Bell, A., Crothers, C., Goodwin, I,. Kripalani, K., Sherman, K., and Smith, P. (2007) The internet in New Zealand - Final Report. Retrieved October $8^{\text {th }} 2009$ from http://www.aut.ac.nzl_data/assets/pdf_file/0004/15655/wipnz_2007_final_repo rt.pdf

Benet-Martinez, V., \& John, O. P. (1998). Los Cinco Grandes across cultures and ethnic groups: Multitrait multimethod analyses of the Big Five in Spanish and English. Journal of Personality and Social Psychology, 75, 729-750.

Bento, R. Brownstein, B. Kemery, E. and Rawson Zacur, S. (2005). A Taxonomy of participation in online courses. Journal of College Teaching \& Learning. 2(12), 79-86.

Bento, R. and Schuster, C. (2003). Participation: The online challenge. In Aggarwal, A. (ed) Web-Based Education: Learning from experience. (pg156-164). Information Science Publishing, PA (USA).

Berkowitz, L. and Lutterman, K. G. (1968). The traditional socially responsible personality. Public Opinion Quartlery. 32 (2), 169-185. 
Bioethics Council of New Zealand. (2009). Who gets born? Retrieved October $8^{\text {th }} 2009$ from http://www.bioethics.govt.nz/about-bioethics/issues-in-focus/prebirthtesting/index.html

Blanchard, A. L. and Markus, M. L. (2002, Jan 7-10th). Sense of virtual community maintaining the experience of belonging. Proceedings from the $35^{\text {th }}$ Hawaii International Conference of System Sciences 2002. Retrieved March $28^{\text {th }} 2009$ from http://ieeexplore.ieee.org/xpls/abs_all.jsp?arnumber=994449

Bock, G.,, Ng, W. and Shin, Y. (2008). The effect of a perceived leaders' influence on the motivation of the members of Nonwork-related virtual communities. IEEE Transactions on Engineering Management. 55(2), 292-303.

Bruce, S. \& Yearley, S. (2006). Sage Dictionary of Sociology. Retrieved May 102008 from http://books.google.co.nz/books?hl=en\&id=Wu1cUcWf1tsC\&dq=\%22Dictionary+of+So ciology\%22\&printsec=frontcover\&source=web\&ots=pNi5a7Ec5\&sig=as7oFCal_9JilPnvhLsOHCZoO5k\#PPA44,M1

Budaev, S. V. (1999) Sex differences in the big five personality factors: Testing an evolutionary hypothesis. Personality and Individual Differences. 26, 801-813.

Byron, K. \& Baldridge, D. C. (2007). E-Mail recipients' impressions of senders' likability: The interactive effect of nonverbal cues and recipients' personality. Journal of Business Communication. 44(2), 137-160.

Chan, C. M. L., Bhandar, M. Oh, L. and Chan, H. (2004, Jan 5-8th). Recognition and participation in a virtual community. Proceedings of the $37^{\text {th }}$ Hawaii Internationa Conference on System Sciences. Retrieved March $29^{\text {th }} 2009$ from http://ieeexplore.ieee.org/xpls/abs_all.jsp?arnumber $=1265460$

Chidambaram, L. and Tung, L. L. (2005). Is out of sight out of mind? An empirical study of social loafing in technology-supported groups. Information Systems Research. 16(2), 149-169.

Costa, P.T., \& McCrae, R. R. (1992). NEO PI-R Professional Manual. Odessa, FL: Psychological Assessment Resources.

Chui, M., Miller, A. and Roberts, R.P. (2009). Six ways to make Web 2.0 work. The McKinsey Quarterly. Retrieved February $20^{\text {th }} 2009$ from http://www.mckinseyquarterly.com/Six_ways_to_make_Web_20_work_2294

Deloitte. (2008). Deloitte Study: Enterprise Value of Online Communities Yet to be Realized. Retrieved July $5^{\text {th }} 2009$ from 
http://www.deloitte.com/dtt/press_release/0,1014,sid\%253D2246\%2526cid\%253D21 $7168,00 . h t m l$

Devaraj, S., Easley, J. And Crant, M. (2008). How does personality matter? Relating the fivefactor model to technology acceptance and use. Information Systems Research. 19(1), 93-105.

Digman, J. M. (1990). Personality Structure: Emergence of the Five-Factor Model, Annual Review of Psychology. 41(1), 417-440.

Eysenck, H. J., \& Eysenck, S. E. G. (1969). Personality and structure and measurement. London: Routledge \& Kegan Paul.

Eysenck, H. J., \& Eysenck, S. E. G. (1975). Manual: Eysenck Personality Inventory. San Diego, CA: Educational and industrial Testing Service.

Eysenck, H.J., \& Eysenck, M. W. (1985). Personality and individual differences: A natural science approach. New York: Plenum Press.

Eysenck, H. J., Barret, P. T., Wilson, G. D., \& Jackson, C. J. (1992). Primary trait measurement of the 21 components of the P-E-N system. European Jounal of Psychological Assessment, 8, 109-117.

Florin, P. R, and Wandersman, A. (1984). Cognitive social learning and participation in community development. American Journal of Community Psychology. 12(6), 689-708.

Florin, P. and Wandersman, A. (1990). An introduction to citizen participation, voluntary organizations, and community development: insights for empowerment through research. American Journal of Community Psychology. 18(1), 41-54.

Forster, D. (April 16 2008). Why companies should have online communities. Retrieved July $5^{\text {th }} 2009$ from http://fastwonderblog.com/2008/04/16/why-companies-should-haveonline-communities/

Goldbert, L. R. (1992). The development of markers for the Big-Five factor structure. Psychological Assessment, 4(1), 26-42.

Hall, H. and Graham, D. (2004). Creation and recreation: motivating collaboration to generate knowledge capital in online communities. International Journal of Information Management. 24(2004), 235-246.

Hamburger, Y. A. And Ben-Artzi, E. B. (2000). The relationship between extraversion and neuroticism and the different uses of the internet. Computers in Human Behavior. 16, 441-449. 
Hudson-Smith, A., Evans, S. Batty, M. and Batty, S. (2002). Online Participation: The Woodberry Down Experiment. UCL Working Paper Series. Retrieved March $28^{\text {th }} 2009$ from http://www.casa.ucl.ac.uk/working_papers/paper60.pdf

John, O.P. \& Srivastava, S. (1999). The Big-Five Trait Taxonomy: History, Measurement, and theoretical Perspectives. In L. Pervin and O.P. John (Eds.), Handbook of personality: Theory and research (2nd ed.). New York: Guilford.

John, O. P., Naumann, L. P., \& Soto, C. J. (2008). Paradigm Shift to the Integrative Big-Five Trait Taxonomy: History, Measurement, and Conceptual Issues. In O. P. John, R. W. Robins, \& L. A. Pervin (Ed)., Handbook of personality: Theory and research (pp. 114158). New York, NY: Guilford Press.

Johnson, P. \& Hanna, A. (2008). New Zealand Police Act - Case Study. The Collaboration Project. Retrived August $2^{\text {nd }} 2009$ from http://plone.e.govt.nz/policy/participation/guide-to-online-participation.html

Johnson, R., B., and Onwuebuzie, A., J. (2004). Mixed methods research: A research Paradigm whose time has come. Educational Researcher. 33(7), 174-26.

Jones, Q., Ravid, G. \& Rafaeli, S. (2004). Information overload and the message dynamics of online interaction spaces: a theoretical model and empirical exploration. Information Systems Research. 25(2), 194-210.

Jones, Q. (1997). Virtual-Communities, virtual-settlements and cyber-archaeology: A theoretical outline. Journal of Computer Mediated Communication. 3(3). Retrieved May 102009 from http://www.blackwellsynergy.com.helicon.vuw.ac.nz/doi/full/10.1111/j.1083-6101.1997.tb00075.x

Joyce, E. \& Kraut, R.E. (2006). Predicting continued participation in newsgroups. Journal of Computer-Mediated Communication. 11, 723-747.

Landers, R. N. and Lounsbury, J. W. (2006). An investigation of big five and narrow personality traits in relation to internet usage. Computers in Human Behavior. 22,283293.

Ling, K., Beenen, G., Ludford,P., Wang, X., Chang, K., Li, X., Cosley, D., Frankowski, D., Terveen, L., Rashid, A. M., Resnick, P., \& Kraut, R. (2005). Using Social Psychology to Motivate Contributions to Online Communities. Journal of Computer-Mediated Communication. 10 (4). Retrieved April $23^{\text {rd }} 2008$ from http://www.blackwellsynergy.com/doi/abs/10.1111/j.1083-6101.2005.tb00273.x

McCrae, R.R. \& Costa, P.T. (1991). Adding Liebe und Arbeit: The full five-factor model and well-being. Personality and Social Psychology Bulletin. 17 227-232. 
McCrae, R. R. \& John, O. P. (1992). An introduction to the five-factor model and its applications. Journal of Personality. 60(2), 175-215.

McElroy, J. C., Hendrickson, A. R., Townsend, A. M., \& DeMarie, S. M. (2007). Dispositional factors in internet use: Personality versus cognitive style. MIS Quarterly. 31(4), 809820.

McMillan D. W. \& Chavis, D. M. (1986). Sense of community: A definition and theory. Journal of Community Psychology. 14(1), 6-23.

Marcus, B. \& Schutz, A. (2005). Who are the people reluctant to participate in research? Personality correlates of four different types of nonresponse as inferred from self- and observer ratings. Journal of Personality. 73(4), 959-984.

Maslow, A. H. (1943). A theory of human motivation. Psychological Review. 50(4), 370-396.

Neilson, J. (2006) Participation inequality: Encouraging more users to contribute. Retrieved April $15^{\text {th }} 2008$ from http://www.useit.com/alertbox/participation_inequality.html

Nielsen/NetRatings (2006). User-Generated content drives half of U.S. Top 10 fastest growing web brands, according to Nielson/NetRatings. Retrieved July $5^{\text {th }} 2009$ from http://netratings.com/pr/PR_060810.pdf

New Zealand Police. (2007). Police act review wiki. Retrieved October $8^{\text {th }} 2009$ from http://www.policeact.govt.nz/wiki/

Porter, C. E. (2004). A Typology of Virtual Communities: A Multi-Disciplinary Foundation for Future Research. Journal of Computer-Mediated Communication. 10 (1) Retrieved May 102008 from http://www.blackwellsynergy.com.helicon.vuw.ac.nz/doi/full/10.1111/j.1083-6101.2004.tb00228.x

Preece, J. (2000). Online communities: supporting sociability, designing usability. New York: John Wiley.

Preece, J., Maloney-Frichmar, D. \& Abras, C. (2003). History of Online Communities. Encyclopedia of Community. Retrieved July $5^{\text {th }} 2009$ from http://www.sageereference.com/community/Article_n365.html

Rheingold, H. (1993) The virtual community: Homesteading on the electronic frontier. New York: Addison-Wesley.

Ridings, C. M. \& Gefen, D. (2004). Virtual Community Attraction: Why People Hang Out Online. Journal of Computer-Mediated Communication. 10 (1), Retrieved May 102008 
from http://www.blackwell-synergy.com.helicon.vuw.ac.nz/doi/full/10.1111/j.10836101.2004.tb00229.x

Rouse, S.V. \& Haas, H.A. (2003). Exploring the accuracies and inaccuracies of personality perception following Internet-mediated communication. Journal of Research in Personality. 37, 446-467.

Schmitt, D. P., Allik, J., McCrae, R. R. \& Benet-Martinez, V. (2007). The geographic distribution of big five personality traits: Patterns and profiles of human selfdescription across 56 nations. Journal of Cross-Cultural Psychology. 38(2), 173-212.

Sharma, P. (2008). Core Characteristics of Web 2.0 Services. Tech Pluto Retrieved October $8^{\text {th }}$ 2009 from http://www.techpluto.com/web-20-services/

Srivastava, S. (2009). Measuring the Big Five Personality Factors. Retrieved March $7^{\text {th }} 2009$ from http://www.uoregon.edu/ sanjay/bigfive.html

State Services Commission. (2007). When government engages: Online participation - an introduction. State Services Commission. Retrieved August $2^{\text {nd }} 2009$ from http://plone.e.govt.nz/policy/participation/online-guide-07.pdf

Sohn, D. and Leckenby, J. D. (2007). A structural solution to communication dilemmas in a virtual community. Journal of Communication. 57, 435-449.

Swickert, R. J., Hittner, J. B., Harris, J. L. and Herring, J. A. (2002). Relationships among internet use, personality, and social support. Computers in Human Behavior. 18, 437451.

Tuten, T., \& Bosnjak, M. (2001). Understanding differences in web usage: the role of need for cognition and the five factor model of personality. Social Behavior and Personality, 29(4), 391-398.

Wandersman, A. (1981). A framework of participation in community organizations. The Journal of Applied Behavioral Science. 17(1), 27-58.

Wikipedia. (2008). Wikipedia: About Us. Retrieved $8^{\text {th }}$ October 2009 from http://en.wikipedia.org/wiki/Wikipedia:About 